\title{
The Kosmètai Portraits in Third Century Athens Recutting, Style, Context and Patronage
}

\begin{abstract}
Portraits of a group of thirty kosmētai, public philosophy teachers in Athens, were found among the fill in the Valerian Wall by the Roman Agora in Athens in 1861. From the Hellenistic period onwards, the kosmētai had taught the philosophy of Aristotle, though with time, the teaching became more varied. In the first century AD the number of students had a peak of three hundred a year. In the third century, when the portraits were buried in the Valerian Wall, the number of students had decreased, much as it had in other pedagogic institutions. The activity of the kosmētai ended about AD 280, when the Valerian Wall was built. The dating of the Valerian Wall is based on coins with the portrait of emperor Probus (AD 276-282), which have been found among the building debris. What we know about the kosmētai from the written sources leads to several questions, such as why the kosmētai portraits were used as building material at a time when the identity of the sitters could still be remembered. Why were some of the portraits recut into those of other individuals shortly before they were put into the wall? Some of the kosmētai portraits were produced, recut and discarded during the span of a few decades. This paper discusses the portraits of the kosmetai and their significance in Roman Athens, and explores questions related to the disposal of them, as well as to context, style, workshop and patronage.
\end{abstract}

\section{Introduction}

The kosmètai were public teachers of the Attic ephebes in Athens from the Hellenistic period to the third century AD. They trained young men of the upper social classes in rhetoric and philosophy with a view to obtain areté. The kosmètai were not professional intellectuals, but normally young magistrates who were appointed, and who contributed to the making of a new philosophical culture in Athens, connected to Sophism. ${ }^{1}$ The concept was originally initiated and developed by Aristotle, and included a group of teachers who were responsible for the Gymnasium. The teaching took place outdoors, in the area around the Roman Agora of Athens. Because of the status of the kosmètai, their portrait statues were erected by local benefactors.

The term 'kosmètes' was inscribed on four of the approximately thirty portraits which were found in 1861 as fill in the so-called Valerian Wall. The portraits formed part of herms,

${ }^{1}$ Zanker 1995, 220. 
which were probably set up in the area where the Byzantine church of Saint Demetrios now stands, close to the Tower of the Winds in the Roman Agora. ${ }^{2}$

The Valerian Wall was built at the time of emperor Probus, around 280 AD, as dated on the basis of coin finds. The older, large Wall of Pericles from the fifth century BC had been destroyed by the Herulian invations in AD 267, and the city had shrunk so much that less extensive fortifications were needed. ${ }^{3}$ The new wall indicates that Athens was in decline in the third century, as was the infrastructure of the Roman Empire in general.

The dating of the Valerian Wall to $\mathrm{AD} 280$ gives a terminus ante quem for the burial of the kosmetai portraits. The span of time between the production of the portraits, the recutting of them and their reuse as building material in the Wall was so brief that it may be assumed that some of the represented individuals were still alive or at least remembered.

The kosmétai portraits differ from those of other individuals, because of the time interval between production, reuse and deposition. 'Biography' is the term used here for the history of a portrait, from the time when it was originally produced till the end of its existence. The portraits of the kosmétai have a particularly interesting history, due to their short existence. They are mentioned in this paper partly because:

a) They were all discovered in the same context and proved to have short 'biographies'.

b) Their style is retrospective, inspired from Classical and Hellenistic portrait types.

c) They were all, except for four examples, recut from earlier effigies, probably in the same. workshop(s). This could only happen if local benefactors sponsored the production of portrait statues. ${ }^{4}$

These three characteristics raise two main questions:

1) Style and context: With whom did the sitters of the kosmetai portraits want to be identified? Why were some of the portraits of original Classical philosopher types recut into those of other individuals briefly before they were put into the City wall? Can the individuals with whom the secondary sitters wanted to be associated be reflected in the portrait types and styles? And what was the relationship between the original portrait and the secondary one in terms of representation? In order to respond to these questions, it is necessary to view the kosmètai portraits within their culturalhistorical context.

2) Workshops and patrons: In matters of reuse, can the technique used for the recutting of the portraits lead to the identification of workshop methods and practices? Why were the kosmetai portraits reused as building material, at a time when the identity of

\footnotetext{
${ }^{2}$ Cache 2009.

${ }^{3}$ For the Valerian Wall, see Theocharaki 2011 in general; for the Post-Herulian Wall, see 133-134 in particular.

${ }^{4}$ For the retrospective character of the portraits of the kosmetai see Krumeich 2004, 132. The three exceptions, which were not recut, are three of the ones with inscriptions that inform that their names were Heliodoros (Lattanzi no. 2), Onasos (Lattanzi no. 7) and Sosistratos (Lattanzi no. 8). The fourth example with an inscription, which has not been recut, is Chrysippos (Lattanzi no. 9). Only one herm can be dated with some certainty, and that is the one of Heliodorus, whose inscription includes a dedication from the Archont Claudius Lysiades Meliteus, who held the position AD 129138; see D'Ambra 2005, 28.
} 
the sitters and the patrons who sponsored the portrait statues could still be remembered?

\section{State of the Art}

In the ancient sources, the kosmetai are mentioned because of their teachings and their social status. The sources to the Sophists of Roman period Athens are mainly Herodes Atticus, Elio Aristides, Dion of Prusa, Favorinus, Lucian, and from the third century AD - which is of the greatest interest here - Dexippus, besides Philostratus. ${ }^{5}$ In addition to earlier sources, such as Plato, the most important sources to Sophism and Sophists are Eunapius' Lives from around $400 \mathrm{AD}$ and Diogenes Laertius Lives of the Philosophers from the third century AD. ${ }^{6}$

Herodes Atticus is of special significance, since he was an active Sophist in Athens at the time when the kosmètai portraits were still made from fresh marble, before the recutting practice started. Since he was an extraordinarily rich citizen, he bestowed many gifts to the city as a benefactor. Portrait statues were probably among his gifts.

Publications on the kosmetai portraits by modern scholars include Paul Graindor, who approached the portraits through epigraphy and established a chronology which set a standard for the dating of the kosmètai portraits. ${ }^{7}$ Hans Peter L'Orange was the next in line to remark on the kosmètai portraits in his seminal work, Studien zur Geschichte des spätantiken Porträts. ${ }^{8}$ The most comprehensive study is the volume I ritratti dei Kosméti nel Museo Nazionale di Atene by Elena Lattanzi, which remains pivotal for the study of the kosmetai portraits. ${ }^{9}$ Marianne Bergmann and Paul Zanker have also commented on the kosmêtai por-

\footnotetext{
${ }^{5}$ See in particular Philostratus, Lives of the Sophists, 1, 1-2. For the other philosophers mentioned here, see Lattanzi $1968,79$.

${ }^{6}$ For Plato's references to Sophism, see e.g. Res publica 1, 337.

${ }^{7}$ Graindor 1915, 241-401.

${ }^{8}$ L'Orange 1933, 9-14.

${ }^{9}$ Lattanzi 1968. In the present text I am using the catalogue numbers of Lattanzi and therefor also the inventory numbers referred to by her, and not those of Kaltsas 2002. The numbering of Granidor can be found in Lattanzi 1968.

In order to avoid confusion, however, I am here presenting a concordance between Lattanzi 1968 and Kaltsas 2002.

Kaltsas cat. no. $683=$ Lattanzi cat. no. $2=$ inv. no. 384 'Heliodoros'

Kaltsas cat. no. $684=$ Lattanzi cat. no. $3=$ inv. no. 392

Kaltsas cat. no. $685=$ Lattanzi cat. no. $7=$ inv. no. 387 'Onasos'

Kaltsas cat. no. $686=$ Lattanzi cat. no. $6=$ inv. no. 416

Kaltsas cat. no. $687=$ Lattanzi cat. no. $4=$ inv. no. 410

Kaltsas cat. no. $688=$ Lattanzi cat. no. $8=$ inv. no. 385 'Sosistratos'

Kaltsas cat. no. $689=$ Lattanzi cat. no. $11=$ inv. no. 405

Kaltsas cat. no. $690=$ Lattanzi cat. no. $12=$ inv. no. 394

Kaltsas cat. no. $691=$ Lattanzi cat. no. $13=$ inv. no. 407

Kaltsas cat. no. $692=$ Lattanzi cat. no. $9=$ inv. no. 386 'Chrysippos'

Kaltsas cat. no. $693=$ Lattanzi cat. no. $16=$ inv. no. 411

Kaltsas cat. no. $694=$ Lattanzi cat. no. $17=$ inv. no. 415

Kaltsas cat. no. $695=$ Lattanzi cat. no. $14=$ inv. no. 389

Kaltsas cat. no. $696=$ Lattanzi cat. no. $15=$ inv. no. 408

Kaltsas cat. no. $697=$ Lattanzi cat. no. $18=$ inv. no. 393

Kaltsas cat. no. $698=$ Lattanzi cat. no. $19=$ inv. no. 412

Kaltsas cat. no. $699=$ Lattanzi cat. no. $21=$ inv. no. 395

Kaltsas cat. no. $700=$ Lattanzi cat. no. $24=$ inv. no. 409

Kaltsas cat. no. $701=$ Lattanzi cat. no. $22=$ inv. no. 388
} 
traits. ${ }^{10}$ Hugo Meyer and Ralf von den Hoff have furthermore included examples of kosmētai portraits in their works, and the descriptions of them in Nikolaos Kaltsas' catalogue Sculpture in the National Archaeological Museum in Athens is a valuable resource. ${ }^{11}$

In a more recent publication, Emanuel Voutiras argued that the portrait of the kosmetes Chrysippos, named by the inscription on the herm to which it belongs, was recut from a portrait of Aelius Verus. ${ }^{12}$ This is an important article in relation to the present text. I agree that the portrait has been recut. I do not oppose to Voutiras' identification, although I would not be certain about the identity of the depicted. About the same time as Voutiras presented his hypothesis, Eve d'Ambra and Ralf Krumeich described the portraits of the kosmetai in the light of the relationship between Classical Greece and Roman times. ${ }^{13}$ Krumeich has also paid attention to the kosmétai portraits' iconographic quotation of ancient philosophers. Lastly, in 2014 Alexandros Andreou published a terracotta portrait of a kosmètes which was found at the southern slope of the Acropolis in $1957 .{ }^{14}$ Andreou dates the portrait to the late second century and sees it in relation to the Second Sophistic. ${ }^{15}$

\section{The Second Sophistic}

Originally, in the Hellenistic period, the Gymnasium of the kosmetai was founded on the basis of Aristotle's philosophy, but gradually, the philosophy of the Gymnasium moved away from being solely based on that of Aristotle, and evolved into a school with more varied philosophical perspectives. ${ }^{16}$ The most important subjects of instruction were - next to philosophy - rhetoric, literature, music and geometry. ${ }^{17}$

The philosophical direction of the kosmètai developed in a direction with a stronger emphasis on Sophism, the nature of which changed considerably over the centuries. At the beginning Sophism was not accepted by all as a serious philosophy. Plato, for one, complained that the Sophists were charlatans who were uneducated and overpaid. ${ }^{18}$

\footnotetext{
Kaltsas cat. no. $702=$ Lattanzi cat. no. $29=$ inv. no. 403

Kaltsas cat. no. $703=$ Lattanzi cat. no. $23=$ inv. no. 390

Kaltsas cat. no. $704=$ Lattanzi cat. no. $28=$ inv. no. 398

Kaltsas cat. no. $705=$ Lattanzi cat. no. $27=$ inv. no. 406

Kaltsas cat. no. $706=$ Lattanzi cat. no. $30=$ inv. no. 396

Kaltsas cat. no. $707=$ Lattanzi cat. no. $26=$ inv. no. 391

Kaltsas cat. no. $708=$ Lattanzi cat. no. $33=$ inv. no. 399

Kaltsas cat. no. $709=$ Lattanzi pl. $37=$ inv. no. 1465 (stele)

Note that Lattanzi cat. nos. 1, 5, 10, 20, 25, 31, 32 are not included in Kaltsas' catalogue.

${ }^{10}$ Bergmann 1977, 80; Zanker 1995, 220-223.

${ }^{11}$ Meyer 1991, 225; von den Hoff 1994, 8; Kaltsas 2002 cat. nos. 683-709.

${ }^{12}$ Voutiras 2005, 480

${ }^{13}$ D'Ambra 2005; Krumeich 2004 and 2008.

${ }^{14}$ Andreou 2014.

${ }^{15}$ In addition to these sources, Harrison 1953 is the publication of the portrait collection from the Athenian Agora, which covers a great number of Greek portraits and which provide important parallels. Dillon 2006 is of significance, since it presents several philosopher portraits, which inspired the looks of the kosmètai. With regard to philosopher portraits, Zanker 1995 should be mentioned. All of these references give, despite their sometimes indirect relevance to the present paper, the best art historical background for the understanding of late Roman period Greek portraiture.

${ }^{16}$ Lattanzi 1968, 15-17 and 31.

${ }^{17}$ Plutarch, Moralia 4: Quaest. Conv. 9, 1, 1.

${ }^{18}$ Plato, Res publica 1, 337d.
} 
In the second century AD, the direction of the Second Sophistic was developed. The 'Second Sophistic' is a literary-historical term applied to the heirs of Sophism - who were the philosophical teachers and writers between the first century and $c 230 .^{19}$ The Second Sophistic, which was an extended form of Sophism, included a wider range of topics. Herodes Atticus was among those who adhered to the Second Sophistic. Philostratus, himself a Sophist, described the philosophy in the following passage: ${ }^{20}$

"We must regard the ancient Sophistic art as philosophic rhetoric. For it discusses the themes that philosophers treat of, but whereas they, by their method of questioning, set snares for knowledge, and advance step by step as they confirm the minor points of their investigations, but assert that they have still no sure knowledge, the Sophist of the old school assumes a knowledge of that whereof he speaks. At any rate, he introduces his speeches with such phrases as "I know", or "I am aware", or "I have long observed", or "For mankind there is nothing fixed or sure". This kind of introduction gives a tone of nobility and self-confidence to a speech and implies a clear grasp of the truth. The method of the philosophers resembles the prophetic art which is controlled by man and was organized by the Egyptians and the Chaldeans and, before them, by the Indians, who used to conjecture the truth by the aid of countless stars; the Sophistic method resembles the prophetic art of soothsayers and oracles. $" 21$

\section{The Gymnasium}

An inscription which was found in the Wall together with the kosmêtai group included the term 'Diogeneion'. It was compared to an inscription in Eleusis referring to the Eleusinion and Diogeneion in that city and led archaeologists to conclude that the finds came from the Diogeneion in Athens. ${ }^{22}$ The Diogeneion was established and dedicated to the Macedonian general Diogenes in 229 BC, hence its name. The Diogeneion in Athens was built in return for the liberation of the city from Macedonian rule, a liberation for which Diogenes had granted a large sum of money.

It is possible that the kosmètai portraits came from the Diogeneion in Athens, but it cannot be proved. According to the written sources the kosmetai were not confined to one particular place, but rather served at several, such as the Academia, Lykeion and Kynosargos. The entire city of Athens was a kind of 'Kulturmetropol', with several portrait statues referring to the grand past, such as retrospective philosopher herms. ${ }^{23}$

The number of students increased rapidly and from the third century BC - that is, from the Hellenistic period and onwards. In the third century BC, the Gymnasium experienced a considerable increase in the number of students, which required a larger number of teachers. At that time, the Gymnasium included 300 students per year, before the Gymnasium closed down and disappeared.

Aristotle had not requested a lower age limit for kosmétai, but in AD 9 the required age was forty years. In the second century $\mathrm{AD}$ it was possible to become a kosmètes at the age of

\footnotetext{
${ }^{19}$ For Sophists in the Roman Empire, see Bowersock 1969.

${ }^{20}$ For Herodes Atticus, see Graindor 1930.

${ }^{21}$ Philostratus, Lives of the Sophists, 1, 1-2. See also Philostratos, Vita Apollonii viii.15.

${ }^{22}$ Lattanzi 1968, 21-23; Krumeich 2004, 133-134.

${ }^{23}$ Krumeich 2004, 147.
} 
$33 .^{24}$ Statistically, in the Roman period, out of 100,000 Roman men, about 44,000 might reach the age of 20. $\mathrm{Ca} 40,000$ would live until the age of 25, and 37,000 until 30. An average of 26,000 would live until 50, and 18,000 to $60 .{ }^{25}$ In other words, about 60 to $70 \%$ of those who attained the required kosmetai age lived until 60, and the healthiest may have been active as kosmetai for about 20 years, before they passed away and younger colleagues inherited the positions.

After their duty at the Gymnasium, the kosmetai were given other offices, and counted as educated individuals, who strengthened the cultural identity of the Greeks, as opposed to the - in the eyes of the Greeks - barbarian Romans.

\section{The portraits of the kosmètai}

The kosmètai portraits are composed by slightly larger than life size images. The inscriptions on some of the portrait herms date between AD 129 and 239, giving the names of four kosmetai and those who dedicated the herms to them. Among the earlier ones are a few portraits which do not seem to have been recut. The names of the kosmetai in this group are Heliodoros, Onasos, Sosistratos and Chrysippos, and from the inscriptions we learn that the dedicators were the ephebes, the Areopagos, the Boulé and the Archont of the year.

The various kosmétai were not necessarily represented with marked personal features, but as rather generic images, which would make the recutting easier. As a group, the portraits must have been larger than life-size in their original phase, and the majority of the kosmettai are still a little larger than an average portrait.

The general features of the kosmetai, which makes it possible to approach them as one group, are as follows:

- vertical notches at the bridge of the nose

- furrowed foreheads

- naso-labial lines

- deep eye sockets

- several examples of cauliflower ears

- unsymmetrically rendered coiffure and beard locks

- hair locks broken at the temples and around the ears

- traces of originally abundant hair styles, which were cut back during the reworking

- remains of original beard tufts under the chin

- coarse surface

- $\quad$ often a square shape of the head ${ }^{26}$

The common features in the kosmètai portraits, which makes them stand out as one type, are reflected in a passage by Dio of Prusa:

\footnotetext{
${ }^{24}$ Lattanzi 1968, 19.

${ }^{25}$ Treggiari 1991, 399; Prusac 2011a, 55.

${ }^{26}$ Several of these terms are used by D'Ambra 2005 in her description of the kosmétai, passim.
} 
"They all wore long hairs and flowing beards, according to the ancient custom, as Homer describes the Greeks. Only a single man was shaven, and he was despised by the rest. They said he did this not for his own enjoyment, but to flatter the Romans and to proclaim his sympathy for them."${ }^{, 27}$

According to Zanker's opinion about the portraits of the kosmetai, ${ }^{28}$ largely based on the passage by Dio, their appearance reflects an attempt to resemble famous Greeks from the past, such as Socrates, Plato, Aristotle, Aeschylus, Theophrastus and Demosthenes. This similarity, however, may be caused by the circumstance that they all seem to have been recut from:

a) earlier portraits of famous Greeks

b) earlier portraits of individuals, such as kosmētai, who wanted to resemble famous ancient Greeks

The kosmetai portraits thus form a group which can be distinguished from others because of their special appearance and their quotations from Classical Greek portrait types. ${ }^{29}$ They were originally made in the second half of the second century $\mathrm{AD}$, but soon after, in the third century, they were recut. With the Herulian invasions of Athens in AD 267, the portraits of the kosmètai were no longer produced, and they seem to immediately have lost their significance. About this time, the number of copies of Greek statuary being made all over the Roman Empire decreased. ${ }^{30}$

The diminishing portrait production coincided with a period of economic decline in the Roman Empire, and reuse of material occurred on a much larger scale than earlier. In these times, portraits were also increasingly reused. The philosopher portraits seem to have been particularly suited for reuse, thanks to their voluminous hair styles and beard, ${ }^{31}$ which provided sufficient material for the recutting of new individuals. Recutting made the production of

\footnotetext{
${ }^{27}$ Dio of Prusa 36, 17.

${ }^{28}$ Zanker 1995, 219-220.

${ }^{29}$ Krumeich 2004, 140-146 compares eight of the kosmètes portraits to earlier philosophers and writers. He uses Lattanzi's catalogue numbers for reference, as I do. For comparisons, he is pointing at Lattanzi nos. 6-8, 16, 22-23 and 30 . The most important parallels which he is drawing are these examples, which are illustrated in his article:

1) Lattanzi no. 8, Soistratos from Marathon, National Archaeological Museum in Athens inv. 385 is compared to Aelius Verus in a collection in Petworth, Slg. Lecondfield.

2) Onasos from Pallene, Lattanzi no. 7, Athens, National Archaeological Museum, inv. no. 387 is compared to the Roman copy of 'Aischylos' in Naples, Athens, Museo Archaeologico Nazionale inv. no. 6139.

3) The kosmètes which I below, in the present text have compared to Plato, is also compared to the same philosopher by Krumeich: Lattanzi no. 30, Athens, National Archaeological Museum inv. no. 396 is compared to the Roman copy of 'Plato' in Münich, Glyptothek, inv. no. 548.

4) Lattanzi no. 16, Athens, National Archaeological Museum inv. no. 411 is compared to Caracalla in Rome, Musei Capitolini inv. no. 2310.

5) Lattanzi no. 23, Athens, National Archaeological Museum inv. inv. 390 is compared to Xenophon in Madrid, Museo del Prado inv. 100-E.

6) The portrait which I below, in the present text, have compared to Aristotle, is by Krumreich compared to Aischines. Lattanzi no. 22, Athens, National Archeological Museum, inv. 388 is compared to Naples, Museo Archaeologico Nazionale inv. no. 6018

${ }^{30}$ Zanker 1995, 320.

${ }^{31}$ Lattanzi 1968; Bergmann 1977, 87.
} 
portraits cheaper, and the art of portrait making was spread on more hands, not always as skilled as their predecessors. The decline in infrastructures made it difficult to transport fresh marble from the quarries. ${ }^{32}$ Consequently the art of portrait making was gradually turned into the art of portrait recutting, and the production of a new kind of images, which shortly afterwards ended up as fill in the Wall. After the Herulian invasion, builders could not be nostalgic. Repairing and fortifying the Wall was urgent. Portraits and sculpture in general could not be a priority, as is also evident in the fact that there was no production at all of portraits in post-Herulian Athens. ${ }^{33}$ Builders were not distinguishing between old, new or newly recut portraits. All kinds of stone were needed.

The quantities of reuse were evident to the excavators, who examined a 65 meter long part of the Wall in 1861 and discovered the portraits of the kosmetai. The lower layers of the Wall were composed by six herm shafts, and the heads were used as fill in the central and upper strata. The shafts measured 0.78-1.49 meters and were made of marble, like the portrait heads. ${ }^{34}$ The find context of the kosmetai portraits in the Valerian Wall also included ephebes and statue bases. ${ }^{35}$ The group of sculpture was evidently haphazardly gathered for the purpose of filling up.

\section{The types of the kosmetai portraits}

The fact that the kosmetai sought to look like earlier, famous Greeks can be seen in the ways by which they wanted to appear. The categorization of kosmetai portrait types which is described below is not an attempt at claiming that all the kosmétai portraits were made from portraits of famous philosophers. ${ }^{36}$ The kosmétai portraits were not necessarily recut from portraits of famous philosophers, but from their followers. It was, however, still common in the third century to exhibit famous philosophers not only in the public areas, but also in private villas, and the number of 'ready-made' examples must have been vast. ${ }^{37}$ The kosmétai portraits, like other Greek portraits, expressed the enduring Athenian identity. ${ }^{38}$ When a kosmètes portrait was recut, something more than just the available material may have been involved.

\footnotetext{
${ }^{32}$ Prusac 2011, 47-50.

${ }^{33}$ Lattanzi 1968, 32.

${ }^{34}$ Krumeich 2004, 136.

${ }^{35}$ Lattanzi 1968, 15.

${ }^{36}$ The present study does not follow the chronological categorization of Graindor and Lattanzi. These authors date the portraits as following:

Lattanzi cat. no. 1 The Julio-Claudian period

Lattanzi cat. no. 2-3 The Trajanic period

Lattanzi cat. no. 4-7 The Hadrianic period

Lattanzi cat. no. 8-13 The Antonine period

Lattanzi cat. no. 14-20 The Severian period

Lattanzi cat. no. 21-27 Between AD 275 and 300

Lattanzi cat. no. 28-33 The Gallienian period.

There is no reason to question this dating with regard to the original portraits. I am arguing that the time period when the original portraits were recut into new ones was the third century.

${ }^{37}$ See Krumeich 2008, 159. For problems related to the distinction between private and public, see Fejfer 2008, 16-17.

${ }^{38}$ Krumeich 2008, 165.
} 
Six groups have here been defined in a demonstration of how the kosmetai portraits were recut, and from what prototype: 1) the Pindar type; 2) the Plato type; 3) the Aristotle type; 4) the Hadrian-Gallienus type; 5) the Tetrarch type and 6) the Ephebe type. When portraits were recut, traits which may seem to be imitations would rather have been remains from the original portrait.

\section{Example 1 The Pindar type $e^{39}$}

This head shows a kosmêtes with a rather rectangular head, due to the cutting back of the original effigy, which was more voluminous (FIGS. $1 \mathrm{a}-\mathrm{b}$ ). It is broken on the left side and on the nose. The surface of the portrait is scarred and bruised. The original may have been an earlier kosmètes who wanted to resemble Pindar, the fifth century lyric poet from Boeotia (FIG. 2). ${ }^{40}$

The reworking is clear because of the toothed chisel marks on the chin, as well as where the skin is hairless and bare (FIGS. $3 \mathrm{a}-\mathrm{b}$ ). The parts with hair have been cut back with a flat chisel, which has made the original hair locks and beard look less vivacious than on the original portrait, remains of which can be identified in some of the locks on the left side of the beard. Most revealing in regard to recutting are the deep-set eyes, which have been cut into the head in order to remove the first pair of eyes. In regard to recutting the fact that the right eye is smaller and semi-closed in both versions of portraits is interesting. It is as if a pronounced trait in the original portrait has been kept and passed on to the next phase. To identify the original as a Pindar-type portrait, the parted locks on the forehead and the hairstyle on the right side of the head should be taken into consideration. The beard is of importance here, since the lower, frontal part is styled in a way characteristic of the Pindar portraits, with the parting of the locks and the collecting of them in a knot of hair beneath the chin.

The secondary portrait has the beard modelled in the same way, whereas the knot has probably been cut away. Furthermore, the moustache is similarly worked as a heavy mass of hair which almost covers the upper lip. The lips of the kosmetes are narrower than in those of Pindar, but that may be due to recutting, since the expression of the mouth is more or less the same.

The depth of the eye sockets indicates that the portrait was recut twice. It is particularly clear when the portrait is seen in profile that the interventions have been through. It was necessary to cut away that much material because the portrait had already been recut. From this we can deduce that some of the portraits were recut more than once.

\footnotetext{
${ }^{39}$ Kosmētes. Athens, National Archaeological Museum, inv. no. 414IN327. Lattanzi 1968, 53-54 pls. 20 a-b; Bergmann 1977, 87; Prusac 2011, cat. no. 240 Figs 26a-b.

The other kosmettai portraits which are counted in this group in this paper are:

Athens, National Archaeological Museum inv. no. 395; Lattanzi 1968, 54-55, no. 21, inv. no. 356IN395.

- $\quad$ Athens, National Archaeological Museum inv. no. 414IN327; Lattanzi 1968, 53-54, no. 20.

${ }^{40}$ For the portraits of Pindar see Richter and Smith 1984, 176-180.
} 


\section{Example 2 The Plato type $e^{41}$}

The Plato type has a long, well-kept beard with wavy curls which reaches down to the top of the sitter's breast. The facial features are elongated (FIG. 4). ${ }^{42}$

In comparison to the Plato portrait, the kosmètes' hair was cut back into a shorter coiffure, and the tip of the beard was shortened (FIGS. 5 a-b and 6 a-b). While the hair has been cut, the beard is still rather long with the wavy strands still falling down toward the breast. However, the strands of hair have been chiseled into waves in a rather summary manner, which seem to be secondary. It is absent in the Plato portrait, which has a softly modelled beard in the Classical fashion. The Plato portrait has a forceful expression, whereas the kosmettes portrait has a more withdrawn countenance. Its eyes are deep-set due to the recutting. Its lips have been left untouched and reveal the shape of the mouth of the original portrait.

\section{Example 3 The Aristotle type}

In the example here, it is first and foremost the coiffure which catches the attention (FIGS. 7 a-b) ${ }^{43}$ The bulging parts of the hair beside each temple are characteristic of the portraits of Aristotle, as are the neatly combed strands of hair from the top of the skull down towards the forehead (FIG. 8). ${ }^{44}$ The forehead of the portrait of Aristotle presents two shallow furrows. Together with the subtle wrinkle at the root of the nose they create a somewhat skeptical expression (FIGS. 9 a-b), which is accentuated by the slope of the mouth. The beard consists of delicately modelled curls running towards the front of the chin, creating a sophisticated

\footnotetext{
${ }^{41}$ The examples in this group are:

Athens, National Archaeological Museum inv. 413; Lattanzi 1968, 37-38 no. 12, inv. no. 352IN 413.

Graindor 1915, 306 fig. 12, inv. no. 394.

Athens, National Archaeological Museum inv. 393; Lattanzi 1968, 51-52 no. 18, inv. no. 235IN393; Graindor 1915, 363 fig. 28.

Athens, National Archaeological Museum inv. 412; Lattanzi 1968, 52-53 no. 19, inv. no. 336IN412; Graindor 1915, 346 no. 18 pl. 20.

${ }^{42}$ For the portraits of Plato see Richter 1965, II, 164-170; Richter and Smith 1984, 181-186.

${ }^{43}$ Kosmētes. Athens, National Archaeological Museum, inv. no. 358. Lattanzi 1968, 62-63 no. 31, inv. no. 348IN397; Prusac 2011 cat. no. 242 figs. 28 a-b. Other examples in this group are: Athens, National Archaeologial Museum. Lattanzi 1968, 48-49 no. 14 [inv. no. 355IN389]; Bergmann 1977, 87. Athens, National Archaeological Museum inv. 413; Lattanzi 1968, 37-38 no. 5 [inv. no. 352IN413]; Graindor 1915, 306 no. 5 fig. 12.

- Athens, National Archaeological Museum inv. 416; Lattanzi 1968, 38-39 no. 6 [inv. no. 349IN416]; Graindor 1915, 311 no. 6 fig. 13.

Athens, National Archaeological Museum inv. 389; Lattanzi 1968,39-40 no. 7 [inv. no. 829IN387]; Graindor 1915, 313 no. 7 pl. 17 'Onasos'.

Athens, National Archaeological Museum inv. 385; Lattanzi 1968, 41-42 no. 8 [inv. no. 827IN385]; Graindor 1915, 380 pl. 18 'Soistratos'.

Athens, National Archaeological Museum inv. 405; Lattanzi 1968, 44-45 no. 11 [inv. no. 355IN405]; Graindor 1915, 376 no. 32 pl. 28.

Athens, National Archaeological Museum inv. 407; Lattanzi 1968, 46-47 no. 13 [inv. no. 338IN407]; Graindor 1915, 332 no. 12 fig. 17.

Athens, National Archaeological Museum inv. 411; Lattanzi 1968, 49-50 no. 16 [inv. no. 357IN411]; Graindor 1915, 342 no. 16 fig. 21.

Athens, National Archaeological Museum inv. 390; Lattanzi 1968, 56 cat. no. 23, inv. no. 390; Graindor 1915, 353 no. 21 pl. 21 ; Prusac 2011 cat. no. 242.

${ }^{44}$ For the portraits of Aristotle see Richter 1965, II, 170-175; Richter and Smith 1984, 95-99.
} 
appearance which the recut kosmetai lack. The similarity between these two portraits is in the shape of the head, including the bulging parts of hair on the sides of the temples, and in the rest of the well-trimmed beard (FIGS. 7-9). The temples are high in both portraits. Where the strands of hair above the forehead on the portrait of Aristotle are turning from left towards right and then again towards the left, those on the kosmētes portrait have been cut midway, where the strands turn to the right. Since the hair has been cut back, the forehead has an extra, horizontal line where the tips of the strands of hair would have been on the original portrait. The eyes of the kosmetes portrait are cut considerably deeper into the head than those of the Aristotle portrait, and they have incised pupils. They give the portrait a more lively expression, but the shape of the eyes has to some extent been kept. The moustache follows the same fashion, and the lips in both portraits are narrow. The first phase of the portrait (which was the copy of the Aristoteles portrait or a portrait which was stylistically influenced by it) can be dated to the second century, on the basis of the beard and the absence of drill holes.

The second phase belongs in the third century, to judge from the 'stitched' or a penna-like punctuation of the eyebrows, and the parts which show bare skin, made with the rasp. Since the kosmetai taught the philosophy of Aristotle, it is hardly a surprise that several of the kosmètai present features that resemble his.

The so-called Heliodorus is another example which might belong in the Aristotle group (FIG. 10). ${ }^{45}$ Its hair has been cropped and at the temples wavy strands of hair follow the directions and curves of the original locks. Indications of the recutting of this portrait are the deeply set eye sockets, where the sculptor has not obliterated a sharp cutting inwards. The depth of the eyes leave no doubt that the portrait has been recut from an earlier portrait, but the original features have been so thoroughly removed that it is difficult to date the first phase.

\section{Example 4 The Hadrian/Gallienus type}

The fourth group was probably originally made at the time of Hadrian, like Example 3 above (FIG. 11). ${ }^{46}$ In the example chosen here, the full coiffure and beard show similarities to the

\footnotetext{
${ }^{45}$ Kaltsas 2002, 325-326 no. 683.

${ }^{46}$ Other examples in this group are:

Athens, National Archaeological Museum inv. 404; Lattanzi 1968, 43 -44 no. 10 [inv. no. 346IN404];

- $\quad$ Graindor 1915, 318 no. 8 fig. 14.

- $\quad$ Athens, National Archaeological Museum inv. 408; Lattanzi 1968, $48-49$ no. 15 [inv. no. 324IN408]; Graindor 1915, 337 no. 14 fig. 19.

- $\quad$ Athens, National Archaeological Museum inv. 415; Lattanzi 1968, $50-51$ no. 17 [inv. no. 337IN415]; Graindor 1915, 362 no. 26 pl. 24.

- $\quad$ Athens, National Archaeological Museum inv. 409; Lattanzi 1968, 57 no. 24 [inv. no. 354IN409]; Graindor 1915, 339 no. 15 fig. 20.

- $\quad$ Athens, National Archaeological Museum inv. 402; Lattanzi 1968, $57-58$ no. 25 [inv. no. 339IN402]; Graindor 1915, 356 pl. 22.

- $\quad$ Athens, National Archaeological Museum inv. 398; Lattanzi 1968, 60-61 no. 28 [inv. no. 340IN398]; Graindor 1915, 360 no. 25 pl. 23; Prusac 2011 cat. no. 245.

- Athens, National Archaeological Museum inv. 403; Lattanzi 1968, 61 no. 29 [inv. no. 325IN403]; Graindor 1915, 369 no. 29 fig. 30.

- Athens, National Archaeological Museum, inv. 347; Lattanzi 1968, $63-64$ no. 32 [inv. no. 347400]; Graindor 1915, 374 no. 31 fig. 32; Prusac 2011 cat. no. 246.
} 
fashion of this emperor (FIG. 12). ${ }^{47}$ The second phase can be dated to the time of Emperor Gallienus (253-268) (FIG. 13). There would be approximately a hundred years between the two phases. It is known that the majority of the portraits of Gallienus were recut from portraits of Hadrian, and it is therefore likely that many non-imperial Hadrianic portraits were recut in the Gallienic period. Gallienus himself was not a philosopher, but he and his wife Salonina had Plotinus as a close advisor. The interest in Hadrian, the lover of all things Greek, especially philosophy, made him a worthy ideal for Gallienus and many of his contemporaries.

The similarity between the portraits of Gallienus and the kosmètes in this example concerns the hairstyle and the beard with the moustache and the thick eyebrows (FIGS. $14 \mathrm{a}-\mathrm{b}$ ). The hair is parted above the forehead and combed in soft waves towards the sides. In the kosmetes portrait the hair above the forehead has been slightly cut back, but the parting of the hair and the waves towards the sides have survived the secondary work with the chisel. The furrowed forehead is smoothed on the kosmetes portrait, whereas the one of Gallienus has two deep lines. The two lines across the forehead may be traces from the hairline of the original portrait of Hadrian.

While the coiffure on the top of the head in the Gallienus portrait has been smoothed out, perhaps because it was not visible from below, the hair on the top of the kosmetes head has locks of hair which have been left almost untouched. Both portraits have deep-set eyes, but those of Gallienus are contracted towards the brows, whereas those of the kosmètes has been widened and made larger as a consequence of the recutting. The sideburns have the same distance to the eyes and the mouth, and the beards are well trimmed. A difference between the two portraits concerns the beard, which covers the entire chin of the kosmetes, while that of Gallienus has left the skin beneath the lower lip bare. Aside from this difference, the way the beard has 'grown' on the throat below the chin in both portraits distinguishes them from other examples of kosmettai, but also of several other contemporary portraits.

\section{Example 5 The Tetrach type}

In addition to these examples there are among the kosmetai portraits a few examples which resemble the images of the soldier emperor portraits or the Tetrarchs (FIG. 15). ${ }^{48}$ The hair has been cut down to a close-cropped hood, with similar treatment of the beard and moustache, as well as of the eyebrows (FIG. 16). The short hair recalls the passage from Dio of Prusa (above), which states that the short haired kosmetai were despised by all the rest, who adhered to the longhaired Classical philosopher style.

\footnotetext{
${ }^{47}$ Athens, National Archaeological Museum, inv. no. 414IN327. Lattanzi 1968, 48-49 pls. 14 a-b; Bergmann 1977, 87; Prusac 2011, cat. no. 240 fig. 26 a-b.

${ }^{48}$ The example used in the drawing of this portrait is not from Lattanzi, but from L'Orange 1933, 108, cat. no. 3 , fig. 13. The other examples in this group are: Athens, National Archaeological Museum inv. 410; Lattanzi 1968, $36-34$ no. 4 [inv. no. 234IN410]; Graindor 1915, 300 no. 3 pl. 16 .

- Athens, National Archaeological Museum inv. 828 'Chrysippos'; Lattanzi 1968, $42-43$ no. 9 [inv. no. 828IN386]; Graindor 1915, 324 no. 10 fig. 15; Prusac 2011, cat. no. 247.

- $\quad$ Athens, National Archaeological Museum inv. 406; Lattanzi 1968, $59-60$ no. 27 [inv. no. 341IN406; Graindor 1915, 358 no. 24 fig. 27.
} 
The eyes have been enlarged compared to those of the original portrait, again showing that this specimen has been recut. The swollen cauliflower ears protrude in a way which indicates that the surrounding material has been removed. Krumeich argues that some of the kosmetai's ears were swollen because of blows to the heads in the often rough athletic games at the Gymnasium. ${ }^{49}$ I suggest that the swollen appearance of the ears was a technical consequence of the recutting.

The Tetrarch type is strikingly different from the other kosmètai portraits, and one may ask if the sitters were kosmetai. Contextually the Tetrarch type belongs to the kosmetai, but not only kosmétai were found in the same part of the Valerian Wall. There were also ephebes. ${ }^{50}$

\section{Example 6 The Ephebe type}

In the find context of the kosmetai portraits there were examples of ephebe portraits with youthful faces (FIGS. 17a b and 18a b). ${ }^{51}$ These have a smoother surface and could originate in an earlier, Classical or Classicizing portrait. Few changes have been made to the heads, except for the close cropping of the hairstyle and the diagonal incising of the eyebrows, which makes them look more naturalistic. A long furrow across the forehead may be a remain from the hairline of the original head. The same could be said about the shallow, punctuated incising of the light, juvenile beard. Both these portraits probably show pupils and not kosmētai.

\section{The style of the kosmètai portraits}

'Un exame, même superficiel, permet de se render compte que les cosmétes forment une série très caractéristique parmi les portraits d'époque impériale'. ${ }^{52}$ Graindor - as in this passage considered the style of the kosmêtai portraits to be distinctive, despite the fact that he, like Lattanzi later, dated them from the Julio-Claudian era to the second century AD, and sorted them into chronological and stylistic groups from these centuries. I suggest that that they were originally from the Imperial period, but were all recut in the third century. ${ }^{53}$ This suggestion needs not entail rejecting all that has been previously written about the dating of the kosmètai portraits. Rather, I understand the dating of the original portraits to the second century AD, as in Eve D'Ambra's discussion of the style of the kosmètai portraits. ${ }^{54}$

Several philosopher style portraits from the troubled third century AD have survived. The National Museum in Athens holds the largest collection of these portraits, which continue a long tradition of philosopher portrait production. The large number of surviving examples makes it difficult to distinguish the portraits of 'real' philosophers from other public individ-

\footnotetext{
${ }^{49}$ Krumeich 2004, 139.

${ }^{50}$ Lattanzi 1968, 15.

${ }^{51}$ The examples in this group are: Athens, National Archaeological Museum inv. 401IN350; Lattanzi 1968, $33-34$ no. 1 'Heliodorus' [inv. no. 350IN401]; Graindor 1915, 290, no. 1 fig. 9; Prusac 2011 cat. no. 248; Athens, National Archae ological Museum inv. 79 391; Lattanzi 1968, 58-59 no. 26 [inv. 326IN391]; Graindor 1915, 354 no. 22, fig. 26; Prusac 2011, cat. no. 244.

${ }^{52}$ Graindor 1915, 278.

${ }^{53}$ Lattanzi 1968, 33. See also Krumeich 2004, 135 on the dating of the kosmetes herms and portraits.

${ }^{54}$ D'Ambra 2005, 203-206 and 207-212.
} 
uals, and private individuals who followed the fashion. Perhaps this fusion of identities contributed to the less critical portrait reuse, which became common in the third century AD, and which we have seen in the kosmètai portraits.

In the discussion on the style of philosopher portraits in Late Antiquity, Zanker writes that "(...) the copyist knew the original (...), but kept only as much of the old physiognomy as was necessary for the subject to be recognizable". ${ }^{55}$ Here, Zanker suggests that the copyists only paid attention to the most prominent facial features of the model. In this paper, I suggest that the reason why these portraits look so non-descript is that they were recut, and that the original form influenced the new version.

Returning to D'Ambra and her discussion on Heliodorus and Onaos in particular, her choice of examples are those that have not been recut. ${ }^{56}$ When she describes these two kosmètai, she uses terms such as 'intricately curled coiffures,' 'well-groomed beards,' 'calligraphic treatment of flesh,' applicable to the second century philosopher portraits. This Zeitgeist or 'period-face' also served as a model for the second phase portraits, but this is sometimes hard to grasp as the recutting altered the style, and shortened the well-groomed beards and curly coiffures.

At the end of her conclusion, D'Ambra notes that the images of the kosmettai, and those of Heliodorus and Onaos in particular, representing what we usually term 'Roman style' in portraiture, outdid the 'Greek style'. What was considered Hellenism in Greek philosopher portraits from the second century was rather a cosmopolitan image. D'Ambra's interpretation is easy to follow and does not exclude my understanding of the first phase of the kosmetai portraits, including the original appearance of Heliodorus and Onaos. The present article, however, considers the second century portraits as the 'background' on which the third century kosmètai portraits were made.

\section{Workshop}

The portrait bust of a philosophy teacher from Aphrodisias, which has been thoroughly described by Smith, has the same features as the kosmètai, although of a much higher quality (FIG. 19). ${ }^{57}$ Contrary to the kosmetai, which belong in the mid-third century, Smith claims that although the Sophist portrait from Aphrodisias at first sight seems to belong there, it rather dates to the mid-fifth century. Regarding the thoughtful looking 'Sophist', there seems to be no traces from recutting, yet it can still be compared to the kosmètai portraits.

The ephebe portrait from the Valerian Wall in the example used here can be compared to the imago clipeata portrait of a boy from Aphrodisias, which according to Smith probably represents a famous pupil from another place, or the son of a local benefactor (FIG. 20). ${ }^{58}$ The same interpretation can be valid for the example of an ephebe in Example 6 above. Smith dates the imago clipeata portrait to the Constantinian period or later, due to the carving technique and the style, while the youth from Athens is dated on the basis of the context and the traces from the recutting to the third century. It could be worth asking whether also the youth in Aphrodisias originally belonged in the third century, and was recut in the fourth.

\footnotetext{
${ }^{55}$ Zanker 1995, 323.

${ }^{56}$ D'Ambra 2005, 204 and 210.

${ }^{57}$ Smith 1990, 148-150.

${ }^{58}$ Smith 1990, 147, pl. XIV.
} 
It is generally difficult to identify a specific recutting workshop on the basis of style, but when it comes to the kosmetai portraits, this might be possible. Lattanzi, based on the dating and quality of the portraits, suggests that one workshop, perhaps two, specialized in kosmētai portraits, the latter producing higher quality examples. Lattanzi has suggested that most of the production was undertaken in a workshop to the south on the Agora, where Evelyn B. Harrison discovered a half-finished herm similar to those of the kosmetai. ${ }^{59}$

At first sight, the recut kosmètai portraits form a heterogeneous group with considerable variations. Previously I presented these portraits as parts of one group, which I referred to as the 'Athens group'. ${ }^{60}$ There is, however, no reason to doubt Lattanzi's sorting of the kosmètai portraits - irrespective of their stylistic differences - into one group, coming from the same workshop (with a few exceptions). ${ }^{61}$

Observations of reuse and how the portraits were recut may point to workshop methods and practices. The closer cropping of the hair, often carelessly undertaken, and the incised lines on the locks of hair in the beard, such as in the kosmètes portrait compared to Plato (above), can be observed in other examples. The sometimes exaggerated removal of material in the eye sockets is among the most repeated features. This can for example be observed in a portrait with an unknown provenience in a collection in Bonn, which might come from the context of the kosmétai at the Athenian Agora. ${ }^{62}$

The kosmètai share the same traits, which make them stand out from other portraits, such as - in most cases - the full beard, the deeply set eyes and the low forehead. The same workshop could have been active in both phases as a local workshop which specialized in kosmêtai portraits and the recutting of them. Some of the portraits were recut shortly after the original production, and were soon after used as fill in the Wall. Thus we have their full 'biographies'. ${ }^{63}$ This rapid reuse may be explained by the nature of the kosmetai in Greek society. They were chosen after they had attained a certain age and therefore held their positions for a relatively short time. This means that there was a fairly rapid turnover in the original manufacture of their portraits, and a large number of replacements must have been required and produced. It is possible that portraits of kosmetai who had retired were recarved into the images of younger colleagues, and that this habit caused a high frequency in the recarving. This may explain why the number of reused kosmètai portraits is so high. It may also explain why some portraits were recut twice.

The fact that all portraits except for one are made of Pentelic marble indicates that the fresh marble came from the same quarry in the first centuries of our era. ${ }^{64}$ The Pentelicon quarry was the nearest one to Athens. The surface of the recut portraits was treated with the

\footnotetext{
${ }^{59}$ Lattanzi 1968, 74; Harrison 1953, 389.

${ }^{60}$ Prusac 2011, 98-99.

${ }^{61}$ Lattanzi 1968, 78.

${ }^{62}$ Zanker 1995, 180-183 and 320-321 compares the kosmetai portraits to one of uncertain provenience in Bonn, which is attributed to Carneades. Zanker identifies the portrait as a late third century version of the Hellenistic portrait type of the philosopher with that name, an anti-Stoic Sceptic who was the head of the Academy in the second century BC. Two Hellenistic examples survive, one in Copenhagen and one in Munich. The similarity of the Bonn portrait to those of the kosmètai is, however, striking, inasmuch as it could come from the same workshop in Athens which made the kosmetai portraits.

${ }^{63}$ Lattanzi 1968, 15 and 37-38, pl. 5; Prusac 2011, 25-29 and 32-34, cat. no. 239-243 and 246-248.

${ }^{64}$ Lattanzi 1968 under each catalogue entry. Her cat. no. 6 is made from a marble with larger crystals.
} 
rasp, the traces of which were not removed. This technique can be observed in other sculptures which were 'refreshed' in the third and fourth centuries AD. ${ }^{65}$

From the similarities in method and tools, and the limited topographical area where the kosmetai portraits were found, it can be suggested that the workshop was on the Agora, as Harrison originally suggested. ${ }^{66}$ Today, when the area is a park of ruins, it is difficult to imagine a busy 'quartiere' around the tower, but the ruins as well as the written sources show that the Agora was a busy place in late antiquity. There were several 'bottegas' in the area, and there might have been a workshop specializing in the production, and recutting of kosmêtai portraits in one of them.

Few portrait workshops in Greece seem to have survived in the fourth century, but farther East, in Asia Minor, Ephesus and Aphrodisias had become important centers for sculpture production. Both these cities produced several philosopher style images. Paul Zanker divides the bearded and beardless late-antique philosopher portraits from Aphrodiasis into two groups. ${ }^{67}$ The first comprises inscribed images of famous Greeks from the past: Aristotle, Socrates, Pindar, Pythagoras and Apollonius (probably the one from Tyana). The second group represents nameless contemporary philosophers: the imago clipeata with the beardless youth (FIG. 20) and Smith's 'Sophist' (FIG. 19). The second group shows similarities to the kosmetai portraits from Athens.

\section{Patrons}

The kosmètai took actively part in the social life of Athens, mostly at the Agora, at the Academy and the Gymnasium. They performed rituals in front of shrines, and they took part in the discussions in the city. The kosmettai could be famous individuals who were sponsored by high ranking persons, but the majority was teachers of little fame. The erection of the kosmetai herms came at the end of their service, as a means of honouring those who had contributed in the education of the citizens. ${ }^{68}$

The financing of the kosmetai portraits came from various sources. Firstly, the ephebes could honour their teachers with portrait herms, as was the case with the one with the name 'Chrysippos' in the inscription. ${ }^{69}$ The sons of a kosmêtes could also pay for the erection of a herm for their father.

The portrait herms could be financed by the city, especially the Boulé, but also the Areopagos. The latter had fixed rules for the erection of kosmetai herms: the name of the Archont or the kosmètai's magister of that year should figure in the inscription. ${ }^{70}$ There seems to have been no rules for the identity of the sponsors - or patrons, and their social status and relationship to the honoured kosmètes could vary.

Archonts, the Boulé, ephebes and relatives aside - we should imagine that wealthy citizens such as Herodes Atticus, who was the city's main benefactor in the second century AD,

\footnotetext{
${ }^{65}$ Hannestad 1994, passim, with examples of the use of the rasp. His hypothesis regarding the refreshed surfaces of the Ara Pacis, however, can be disputed.

${ }^{66}$ Harrison 1953, 17, 49 and 92, note 16.

${ }^{67}$ Zanker 1995, 294-295.

${ }^{68}$ Krumeich 2004, 136.

${ }^{69}$ Lattanzi 1968, 21.

${ }^{70}$ Lattanzi 1968, 23-24.
} 
might have been the kind of person who dedicated portrait herms of kosmetai (FIG. 21). His interest in philosophy is well known, and since he, like the kosmetai, was an adherent to the Second Sophistic, is reasonable to assume that he, like other benefactors, paid his share of the kosmetai herms. It is also worth questioning to what degree emperors such as Hadrian, Marcus Aurelius and Gallienus, who were all interested in philosophy and whose images are reflected in the style of those of the kosmetai, sponsored portrait statues in Athens.

\section{Concluding remarks}

The kosmetai portraits have received less attention than they deserve, in view of their importance as a rare and informative group from late-antique Athens. The most significant publication is Lattanzi's volume, including a catalogue, which is based on Graindor's important study. The present article is connected with style and workshop, and particularly recutting.

This contribution interprets all the kosmetai portraits as recut from earlier ones. Interestingly, Lattanzi touched upon the possibility of recutting in her comments to one of the kosmètai portraits in Athens, National Archaeological Museum (inv. no. 413). There she notes that the kosmetes portrait bears a strong resemblance to a portrait in the Capitoline $\mathrm{Mu}-$ seum, which was heavily reworked in Hadrianic times. ${ }^{71}$ This portrait may originally have dated from the Hadrianic period and was reworked, perhaps at the time of Gallienus, when the recutting of Roman portraits reached a peak empire-wide. ${ }^{72}$ In the third century $A D$, when the portrait statues had become so many that they virtually created 'forests' in the public areas of the cities and towns, they seem to have gone out of fashion. As a consequence there were hundreds of portrait statues which no longer had significance, many of them showing long forgotten individuals. Other portraits must originally have represented recently deceased - or perhaps even living ones - who were not forgotten. If some of the portraits showed individuals who were still alive, we are probably dealing with a unique situation.

In the introduction, I posed a few questions to which it is due time to return. The first questions were related to context and style, the rest with regard to workshops and patrons. Context may be divided into 'archaeological context' and in 'cultural-historical context'.

The archaeological context of the kosmetai portraits was as fill in the Valerian Wall. The cultural-historical context, looking back to Roman Athens, must be seen against the backdrop of Plato's Academy, and the tradition of the Sophists, who trained the ephebes by means of philosophy and rhetoric. The Sophists were active from Hellenistic times till the sack of Athens by the Herulians in $\mathrm{AD} 267$, when the economic situation completely altered life in the city. The terminus ante quem for the kosmetai portraits is $\mathrm{AD} 280$, when the part of the Wall where they were found, was built.

It is clear from the portraits of the kosmettai that they wanted to be identified with famous men of the Classical and Hellenistic period, which is why they are represented with hairstyles and beards that allude to specific philosophers, such as Plato and Aristotle. When the portraits were later recut, the hairstyle and the beard still mattered, since the sitters of both the original and recut version apparently wanted to identify themselves with the same famous philoso-

\footnotetext{
${ }^{71}$ Lattanzi 1968, 37 no. 5.

${ }^{72}$ Prusac 2011, 52-54.
} 
phers. There is no reason to doubt that the portraits showed kosmètai both in the first and in the second phase, as the similarity between them in both phases is obvious.

In order to explain the possibility that the kosmètai portraits in the secondary phase could inherit portraits of famous philosophers, with whom they wanted to be associated, we can propose two ways: when one kosmètes passed away, his portrait could become available for his successors, or portraits of deceased kosmetai could be returned to the workshops. In the workshops they could be acquired by customers, who wanted to honour new kosmètai. The choice of material depended on what the workshop had had to offer when a new portrait was requested. The customers seem to usually have acquired earlier kosmétai for the making of new ones. Some, such as the specimen compared to Pindar above, could even be recut twice. We cannot know if the expenses were conditioned by the material, but it seems probable that an already reused portrait would be cheaper than one which had only been recut once.

The question why some of the portraits of a famous philosopher type were recut into those of other individuals shortly before they were put into the Wall is difficult to answer. The best explanation seems to be that the sitters of certain portraits died shortly after having been represented in sculpture, and that their portraits were passed on to younger colleagues. When the Herules arrived, the Gymnasium and the fundament of existence for the kosmetai were destroyed. It is no reason to doubt Lattanzi's assertion that no kosmètes portrait was made after the sack of Athens in AD 267, when the need for material caused an abrupt end to the 'biographies' of the kosmetai portraits. There was no room for nostalgia. ${ }^{73}$

One final question to which it is difficult to responded, regards the patron's role before, during and after the portraits were made and recut. It is tempting to look towards rich individuals such as Herodes Atticus for patronage and financing of the kosmetai portraits. Herodes Atticus is known to have had a great interest in philosophy, and since some of the benefactors of the city honoured the kosmetai with portraits, it is possible that he was one of the patrons in the second century. In the third century, when the kosmettai portraits were recut, there must have been other sponsors, who were not necessarily famous.

Because of the many uncertainties regarding the kosmètai portraits, they remain an intriguing group. This paper has argued that the kosmètai portraits, probably all of them, were recut from earlier versions. The find context and the similarities in the craftsmanship make them a rare example of a group of portraits which may derive from the same workshop.

An updated view on the production and recutting techniques in the making of the kosmetai portraits adds to our understanding of them as a limited group of portraits made at a time when it had become common to reuse sculpture from the past. The use of kosmetai portraits as fill in the Valerian Wall at the time of Probus reduced them to mere material, depriving them of other functions such as artistic and aesthetic values, the memory of lost ones and the status of a particular social group.

Marina Prusac

University of Oslo

m.p.lindhagen@khm.uio.no

\footnotetext{
${ }^{73}$ Nostalgia is not an ancient Greek term, but a seventeenth century construct, based on two Greek words, vó $\sigma \tau \varsigma$ (nóstos) homecoming - and ó̉yos (álgos) - pain. See e.g. Matt forthcoming.
} 


\section{BIBLIOGRAPHY}

\section{Ancient sources}

Dio Chrysostomus, Orationes: Dio Chrysostom in five volumes (The Loeb classical library vol. 385, 19321951), London.

Philostratus, Lives of the Sophists: The lives of the sophists (The Loeb classical library vol., 134, 1921), London.

Plato, Res publica (The Loeb classical Library vol. 237, 2013), Cambridge, Mass. 2013

Plutarch, Moralia vol. 4: Quaestiones Convivale (The Loeb classical library vol. 305, 1936), Cambridge, Mass.

\section{Modern sources}

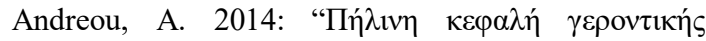

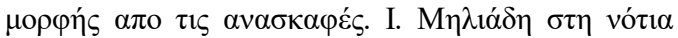

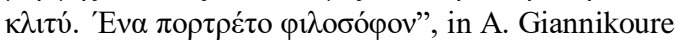

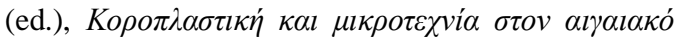

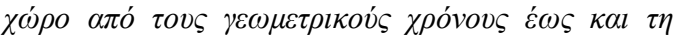

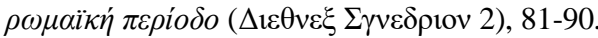

Basset, S. 2004: The Urban Image of Late-Antique Constantinople, Cambridge.

Bergmann, M. 1977: Studien zur römischen Porträt des 3. Jahrhunderts n. Chr., Bonn.

Bowersock, G.W. 1969: Greek Sophists in the Roman Empire, Oxford.

Cache, B. 2009: "The Tower of the Winds of Andronikos of Kyrros: An Inaugural and Surprisingly Contemporary Building", Architectural Theory Review 14.1, 3-18.

D’Ambra, E. 2005: “Kosmetai, the Second Sophistic and Portraiture in the Second Century", in J.M. Barringer, J.M. Hunt (eds.), Perikles, Athens and its Legacy, Austin, 201-216.

Dillon, S. 2006: Ancient Greek Portrait Sculpture. Contexts, Subjects and Styles, Cambridge.

Fejfer, J. 2008: Roman Portraits in Context (Image and Context 2), Berlin.

Graindor, P. 1915: Les cosmètes du Museé d'Athènes (BCH 39), 241-401.

Graindor, P. 1930: Un milliardaire antique: Hérode Atticus et sa famille, Paris.

Hannestad, N. 1994: Tradition in Late Antique Sculpture, Århus.
Harrison, E.B. 1953: Portrait Sculpture. (The Athenian Agora 1: Results of the Excavations Conducted by the American School of Classical Studies at Athens), Princeton.

Helbig, W. 1966: Führer durch die öffentlichen Sammlungen klassischer Altertumer in Rom II. Die Städtischen Sammlungen. Kapitolinische Museen und $\mathrm{Mu}$ seo Barraco, Tübingen.

Kaltsas, N. 2002: Sculpture in the National Archaeological Museum in Athens, Athens and Los Angeles.

Krumeich, R. 2004: “Klassiker' im Gymnasion. Bildnisse attischer Kosmeten der mittelern und späten Kaiserzeit zwischen Rom und griechischer Vergangenheit", in B. Borg (ed.), Paideia: The World of the Second Sophistic (Millenium-Studien zu Kultur und Geschichte des ersten Jahrtausends n. Chr.), Berlin and New York, 131-155.

Krumeich, R. 2008: "Vergegenwärtigung einer 'großen' Vergangenheit. Zitate älterer Bildnisse und retrospektive Statuen berühmter Athener im Alten der römischen Kaiserzeit", in H. Junker, A. Stähli (eds.), Original und Kopie. Formen und Konzepte der Nachahmung in der antiken Kunst. Aktens des Kolloquiums in Berlin 17.-19. Februar 2005, Wiesbaden, 159-175.

Lattanzi, E. 1968: I ritratti dei Cosmeti nel Museo Nazionale di Atene (Studia archaeologica 9), Rome.

L'Orange, H.P. 1933: Studien zur Geschichte des spätantiken Porträts (Serie B: XXII, Instituttet for Sammenlignende Kulturforskning), Oslo.

Matt, S. forthcoming (2018): "Recovering Emotions from Visual Culture", in H. von Ehrenheim, M. Prusac-Lindhagen, Reading Emotions from Ancient Visual Culture. The Semiotics of a Pre-Modern World (Opuscula of the Swedish Institute in Rome).

Meyer, H. 1991: Antinoos. Die archäologischen Denkmäler unter Einbeziehung des numismatischen und epigraphischen Materials sowie der literarischen Nachrichten. Ein Beitrag zur Kunst- und Kulturgeschichte der hadrianisch-frühantoninischen Zeit, Munich.

Prusac, M. 2011: From Face to Face. Recarving of Roman Portraits and the Late-Antique Portrait Arts (Monumenta Graeca et Romana 18), Leiden and Boston.

Richter, G.M.A. 1965: The Portraits of the Greeks IIII, London. 
Richter, G.M.A., Smith, R.R.R. 1984: The Portraits of the Greeks, abridged and revised by R. R. R. Smith, Oxford.

Smith, R.R.R. 1990: "Late Roman Philosopher Portraits from Aphrodisias", JRS 80, 127-155.

Smith, R.R.R. 1999: "Late antique portraits in a public context: Honorific statuary at Aphrodisias in Caria, AD 300-600", JRS 89, 155-189.

Stuart Jones, H. 1912: A Catalogue of the Ancient Sculptures Preserved in the Municipal Collections of Rome: The Sculptures of the Palazzo dei Conservatori, Oxford.

Theocharaki, A.M. 2011: "The Ancient Circuit Wall of Athens: Its Changing Course and the Phases of Construction", Hesperia 80.1, 71-156.
Treggiari, S. 1991: Roman Marriage: Iusti Coniuges from the time of Cicero to the time of Ulpian, Oxford.

von den Hoff, R. 1994: Philosopheporträts des Frühund Hochhellenismus, Munich.

Voutiras, E. 2005: "Beobachtungen zu einem Athenischen Kosmetenporträt"“, in M. Şahin, İ. Hakan Mert (eds.), Ramazan Özgan'a Armağan. Festschrift für Ramazan Özgan, Istanbul, 475-482.

Zanker, P. 1995: The Mask of Socrates. The Image of the Intellectual in Antiquity, Berkeley. 

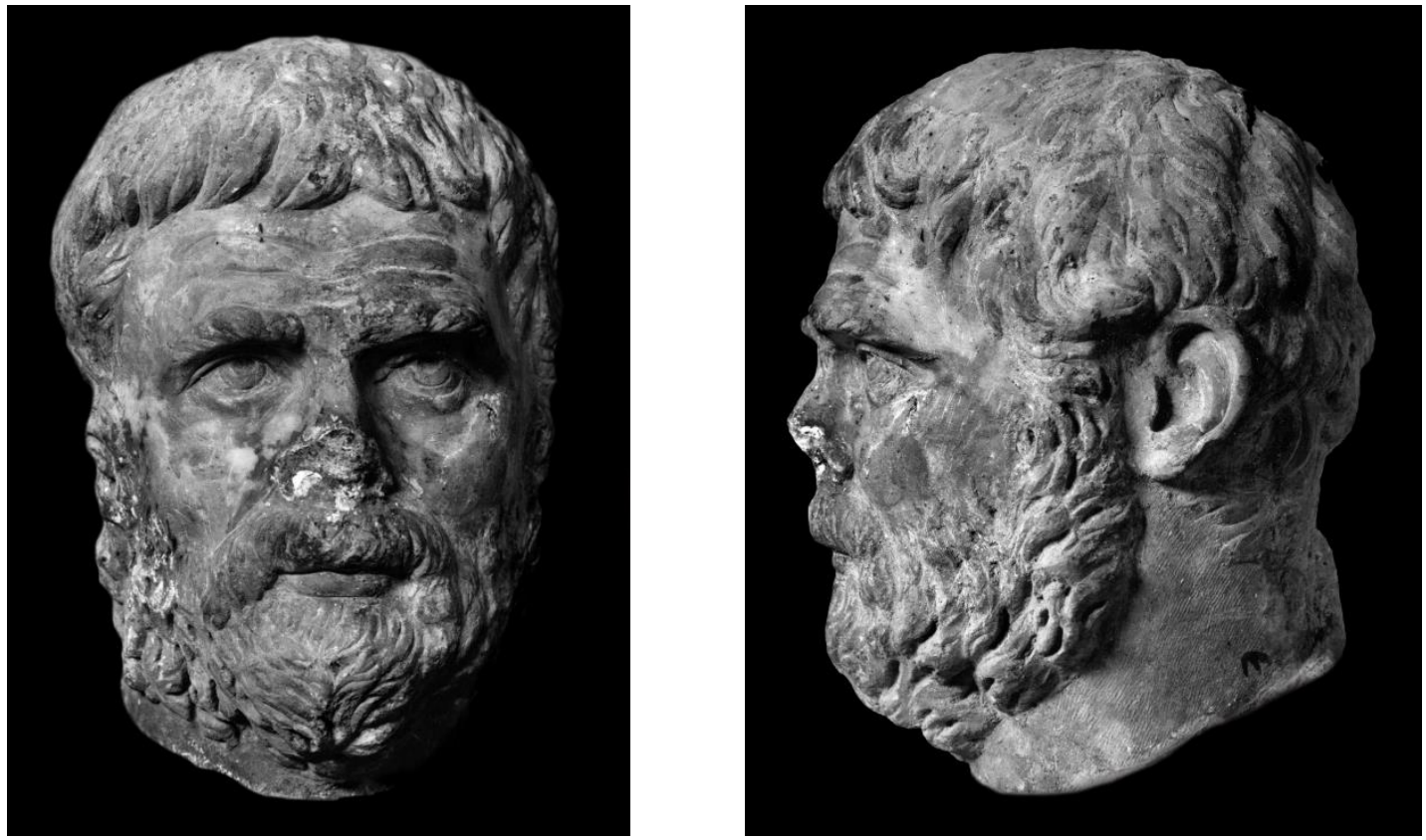

FIgs. $1 \mathrm{a}-\mathrm{b}$ - Kosmētes. Athens, National Archaeological Museum, inv. 414. Photo: Negs. DAI Abt. Athen, NM 531a-b.

FIG. 2 - Pindar, Roman copy of Greek $5^{\text {th }}$ century BC bust. Napoli, Museo Archeologico Nazionale, inv. 6144. Photo: Wikimedia Commons. Photo: Stas Kozlovsky for Wikimedia Commons, license CC BY-SA 3.0.

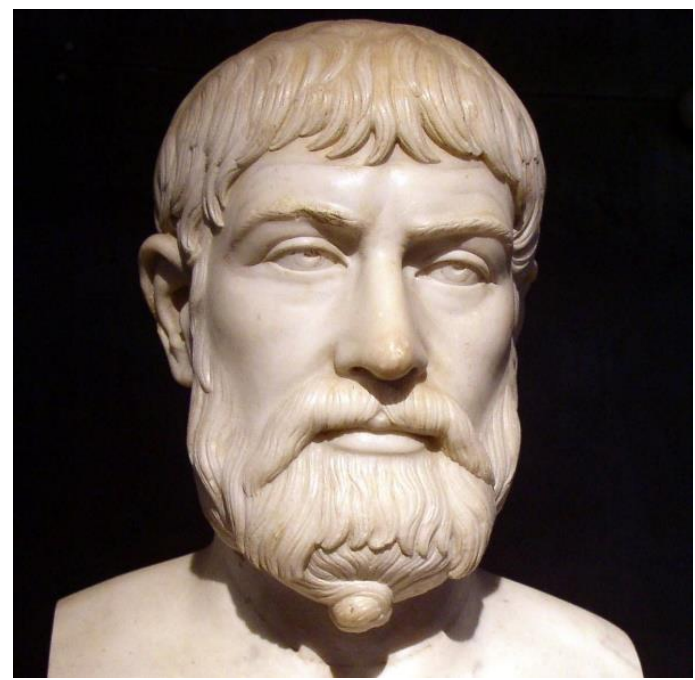



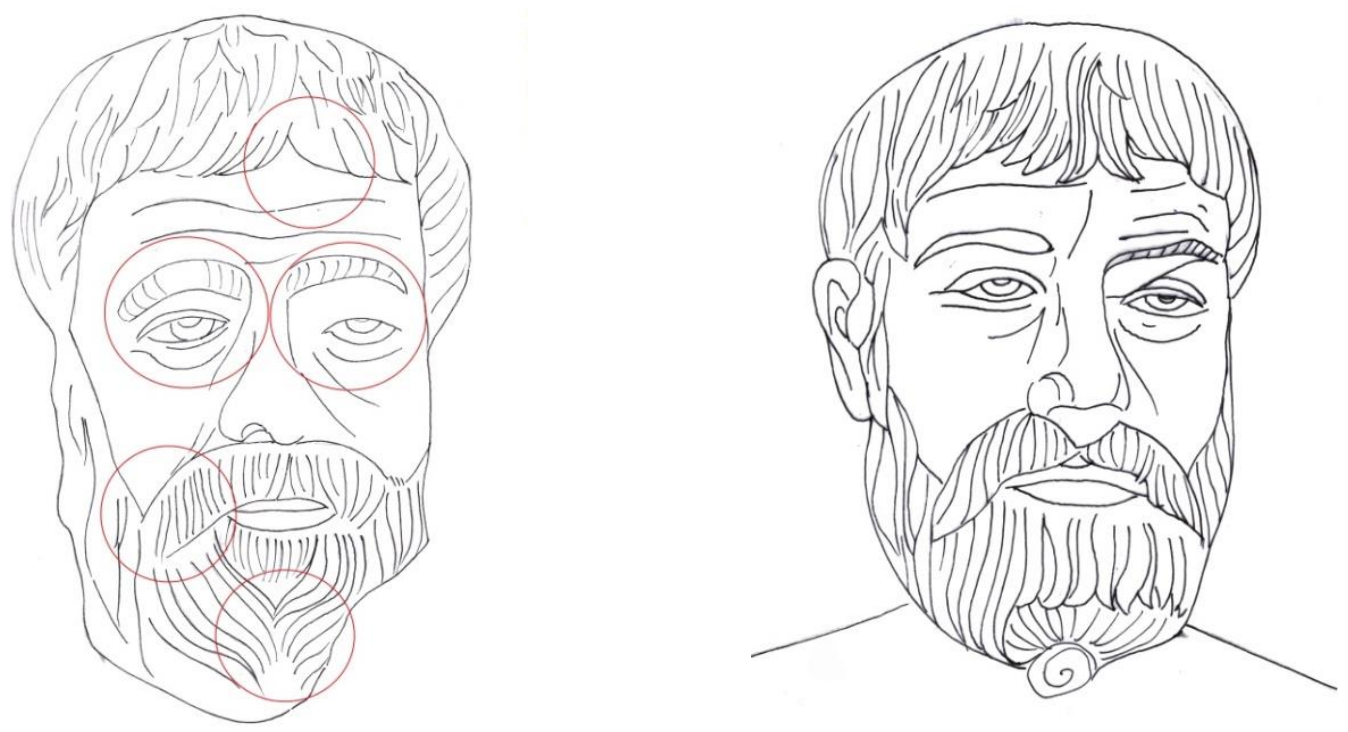

FIGS. $3 \mathrm{a}-\mathrm{b}$ - Drawings with marks of recutting of the same portraits as in Figs. 1-2.

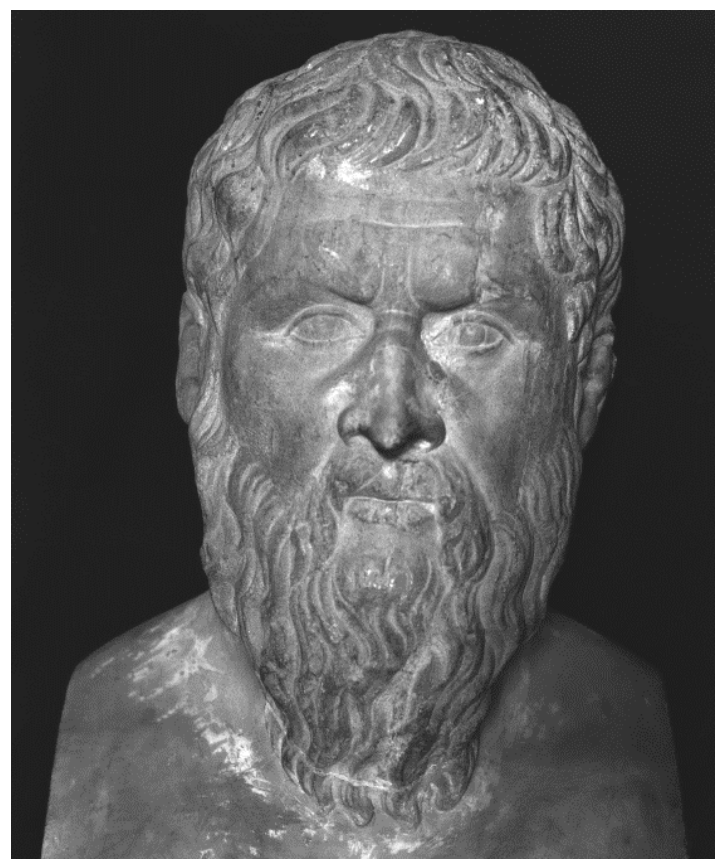

FIG. 4 - Plato, marble portrait bust, from an original of the $4^{\text {th }}$ century BC. Rome, Musei Capitolini, inv. 571. Photo: Wikimedia Commons. 

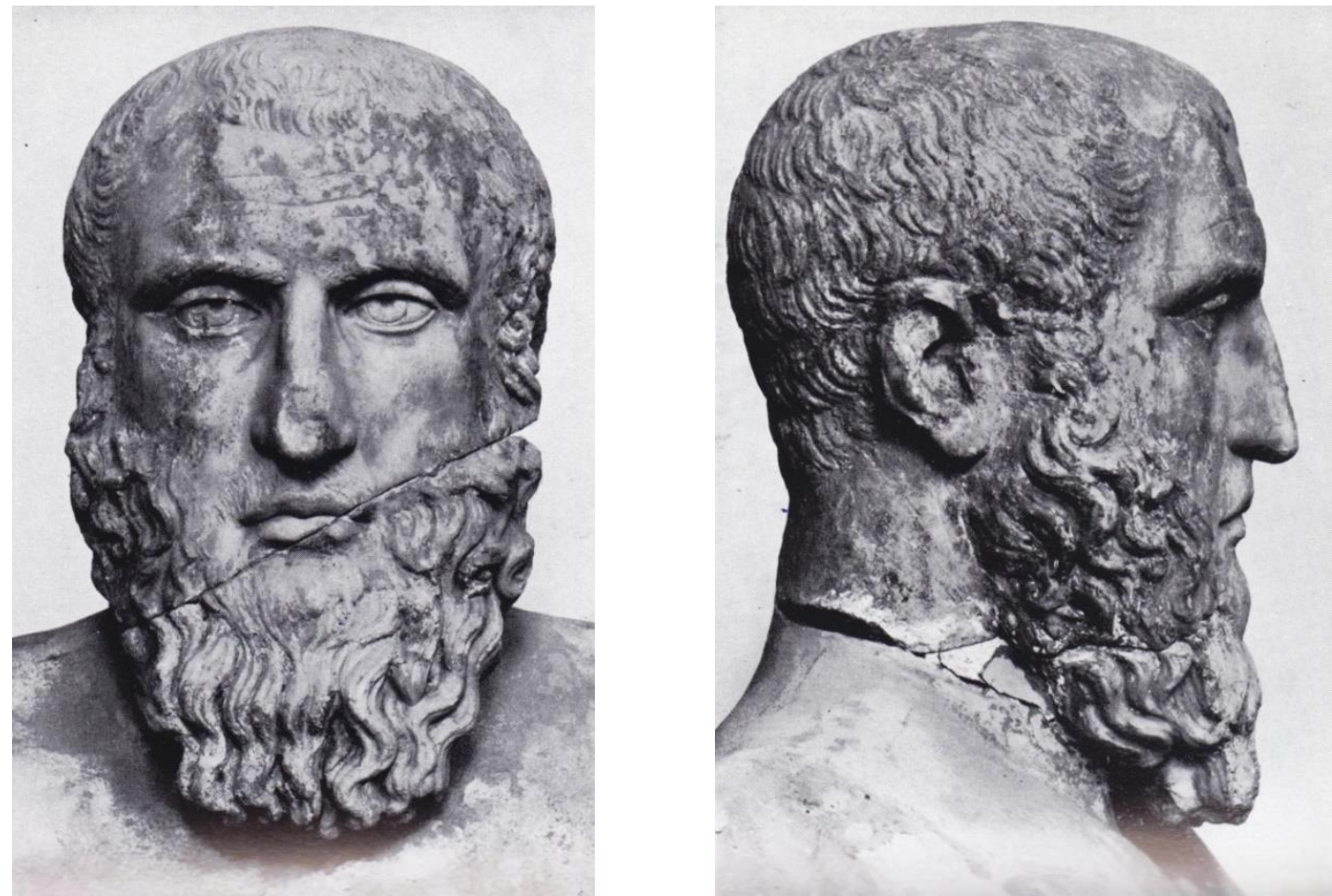

FIgS. 5 a-b - Kosmētes. Athens, National Archaeological Museum, inv. 396. Photo: Lattanzi 1968 no. 30 , pl. 30.
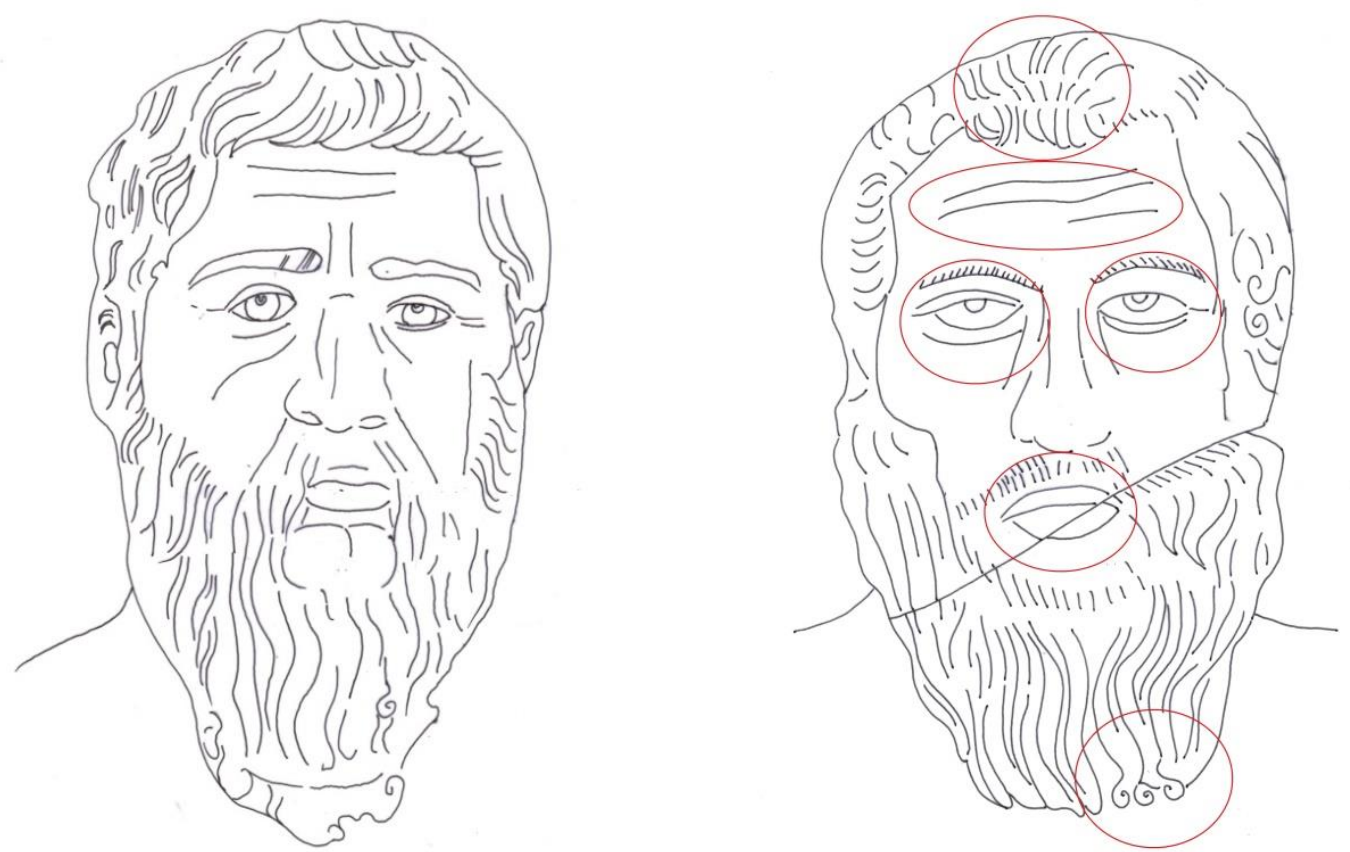

FIGS. $6 \mathrm{a}-\mathrm{b}$ - Drawings with marks of recutting of the same portraits as in FIGS 4-5. 

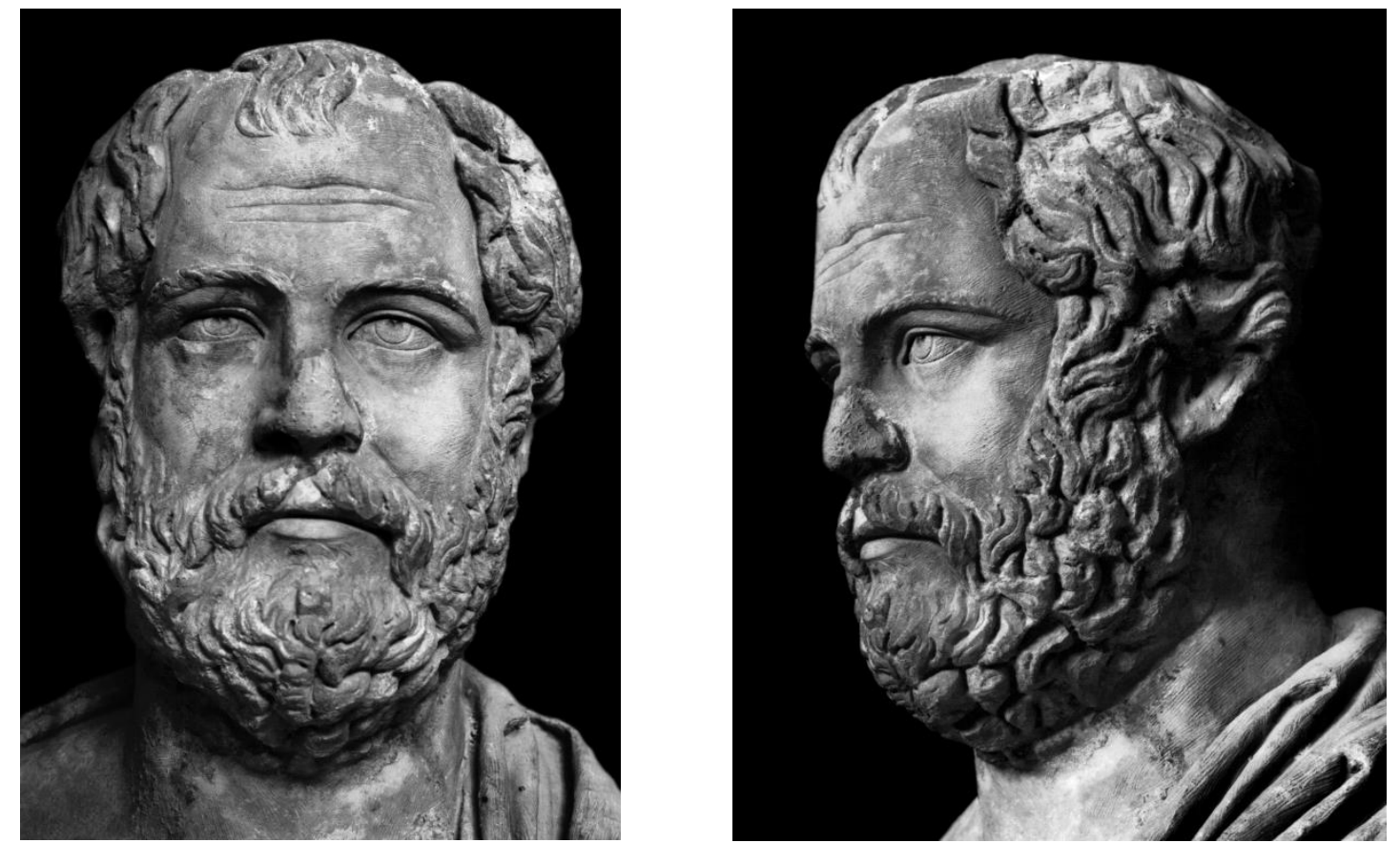

Figs. 7 a-b - Kosmētes. Athens, National Archaeological Museum, inv. 388. Photo: Negs. DAI Abt. Athen, NM 546a-b.

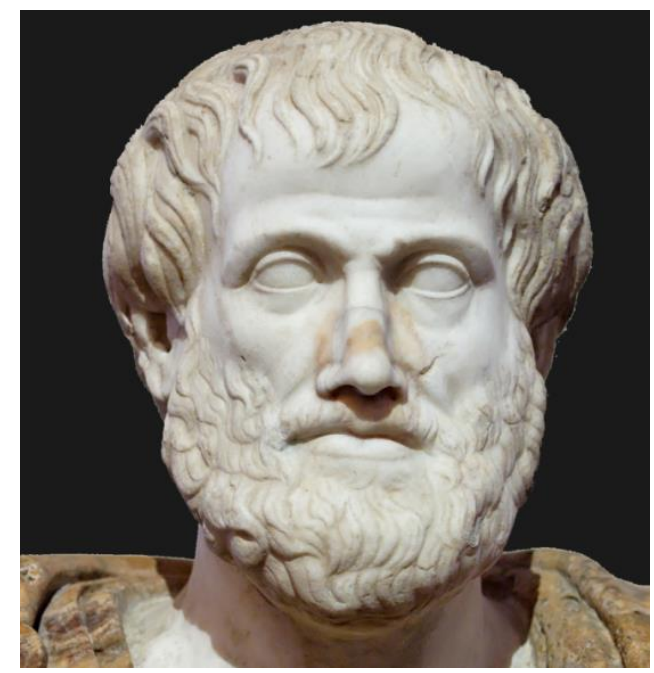

FIG. 8 - Aristotle. Rome, Palazzo Altemps, inv. 8575. Photo: Wikimedia Commons. Photo: Marie-Lan Nguyen ('Jastrow) for Wikimedia Commons, license CC BY-SA 3.0. 

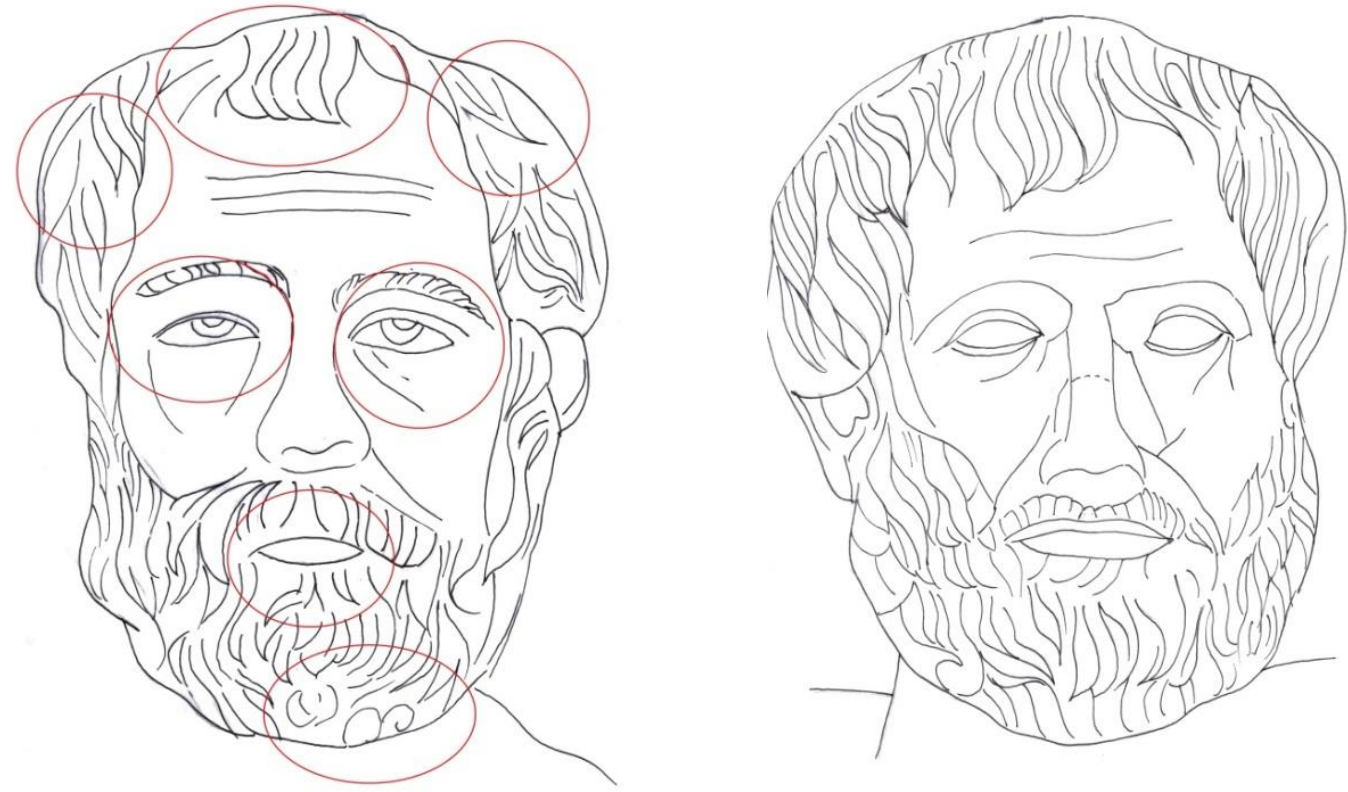

FIGs. $9 \mathrm{a}-\mathrm{b}$ - Drawings with marks of recutting of the same portraits as in FIGS 7a-b and 8 .

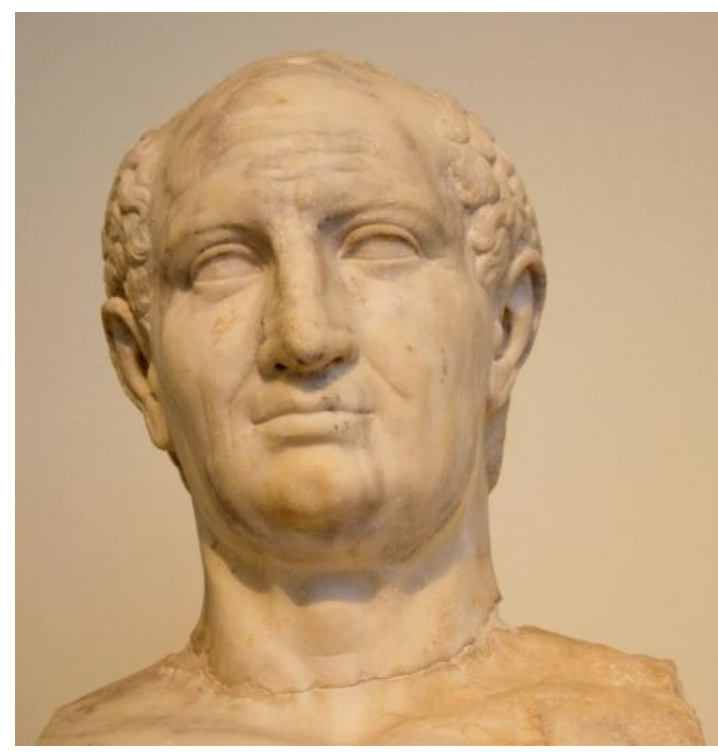

FIg. 10 - Heliodorus. Athens, National Archaeological Museum, inv. 384. Photo: Wikimedia Commons. Photo: Giovanni Dall'Orto for Wikimedia Commons, license CC BY-SA 3.0.

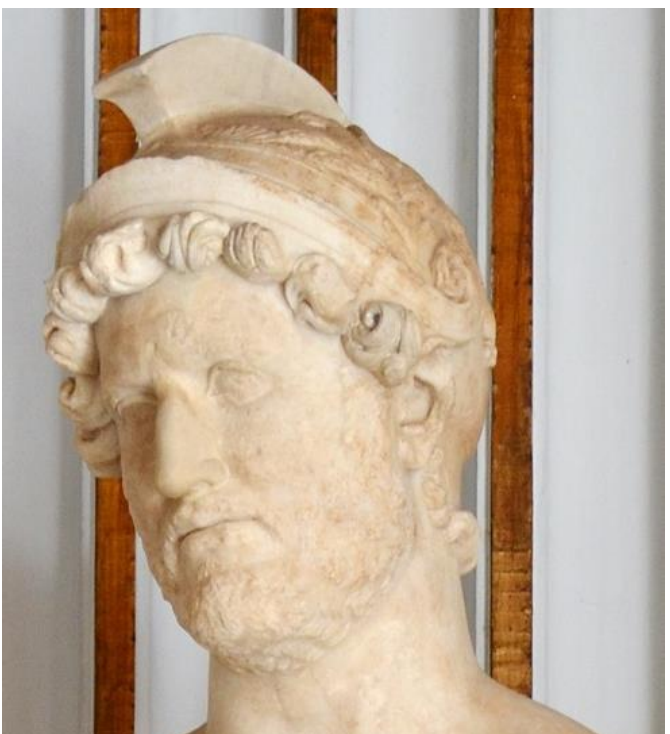

FIG. 11 - Hadrian as Mars. Portrait type 'Vatican Chiaramonti 392,' early Hadrianic. Rome, Musei Capitolini, inv. 634. Photo: Wikimedia Commons. 


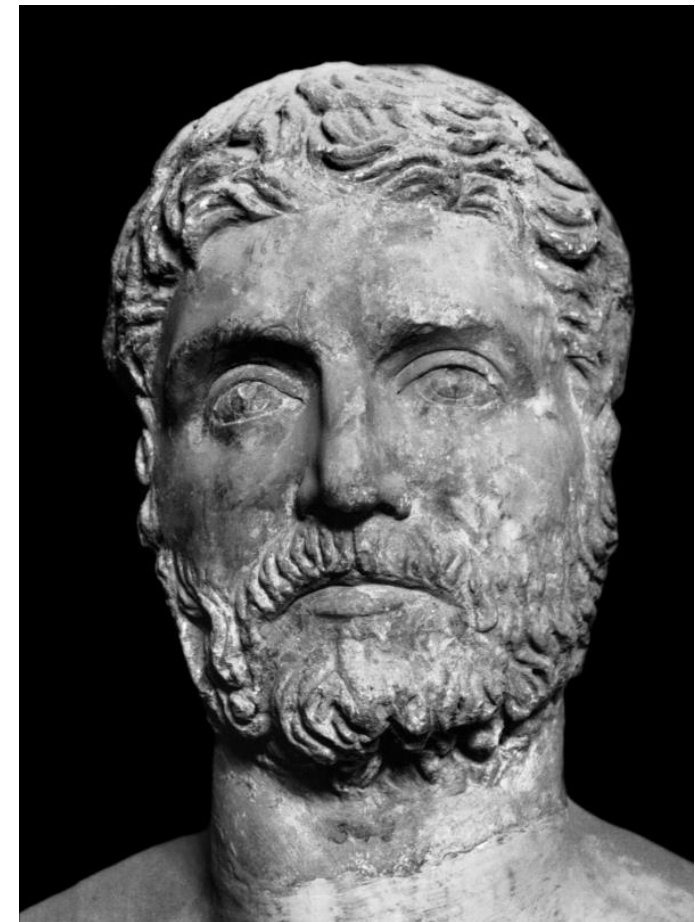

FIG. 12 - Athens, National Archaeological Museum, inv. 389. Photo: Negs. DAI Abt. Athen NM 85a.

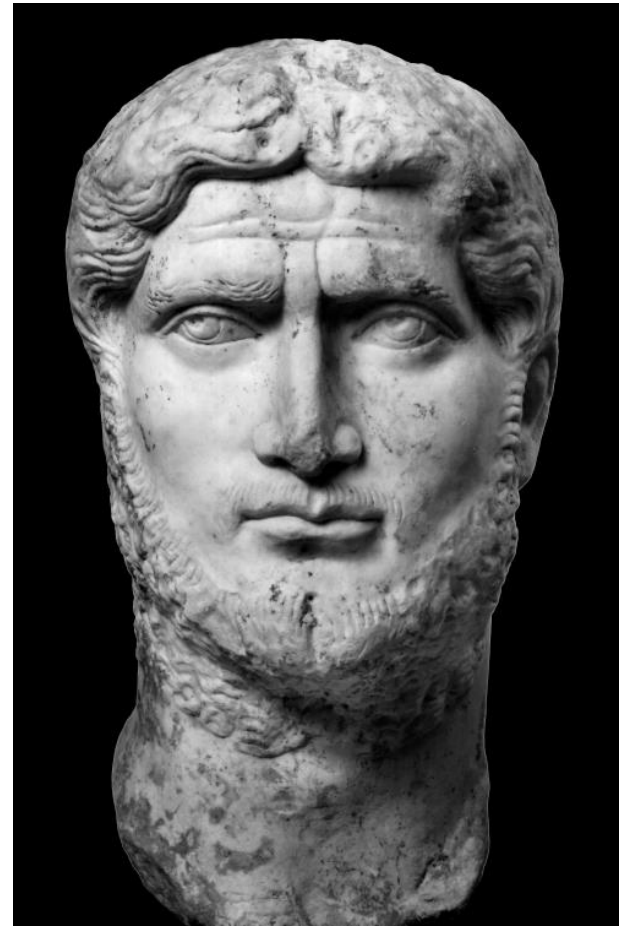

FIG. 13 - Gallienic portrait recut from Hadrianic, possibly showing emperors in both phases. Copenhagen, $\mathrm{Ny}$ Carlsberg Glyptotek, inv. 832. Photo: Ole Haupt.
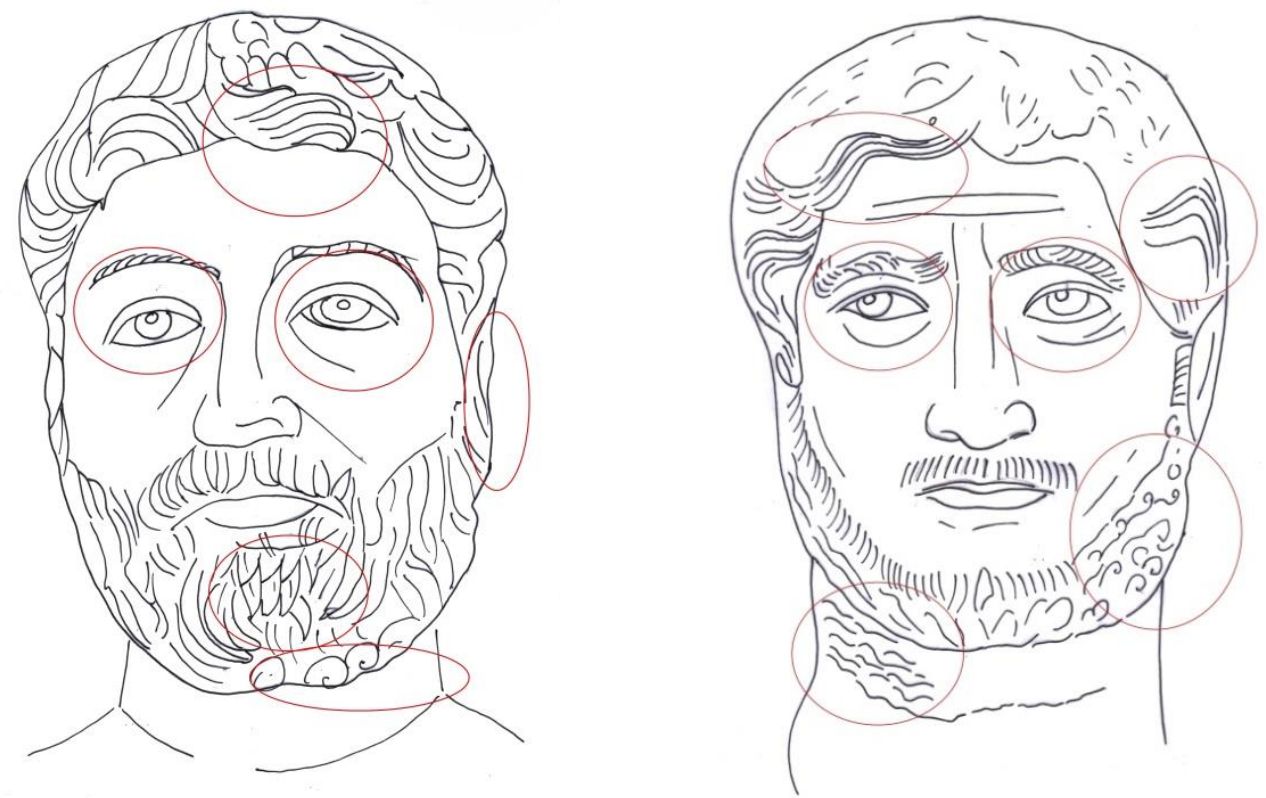

FIG. $14 \mathrm{a}-\mathrm{b}$ - Drawings with marks of recutting of the same portraits as in FIGS. 13-14. 

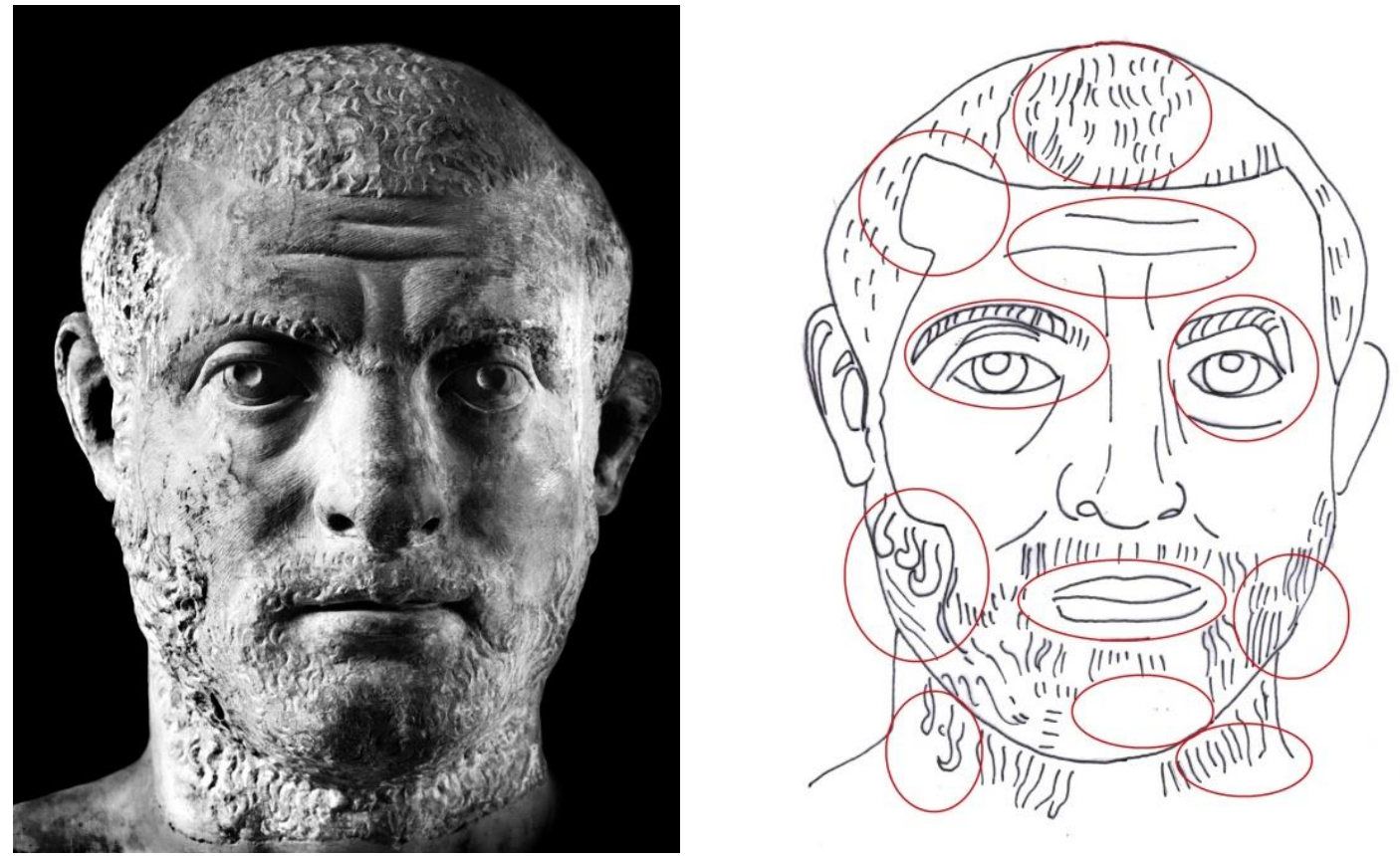

FIG. 15 - Athens, National Archaeological Museum, inv. 400. Photo: Negs. DAI Abt. Athen, NM 516 a.

FIGS. 16 - Drawings with marks of recutting of the same portraits as in FIGS 15.
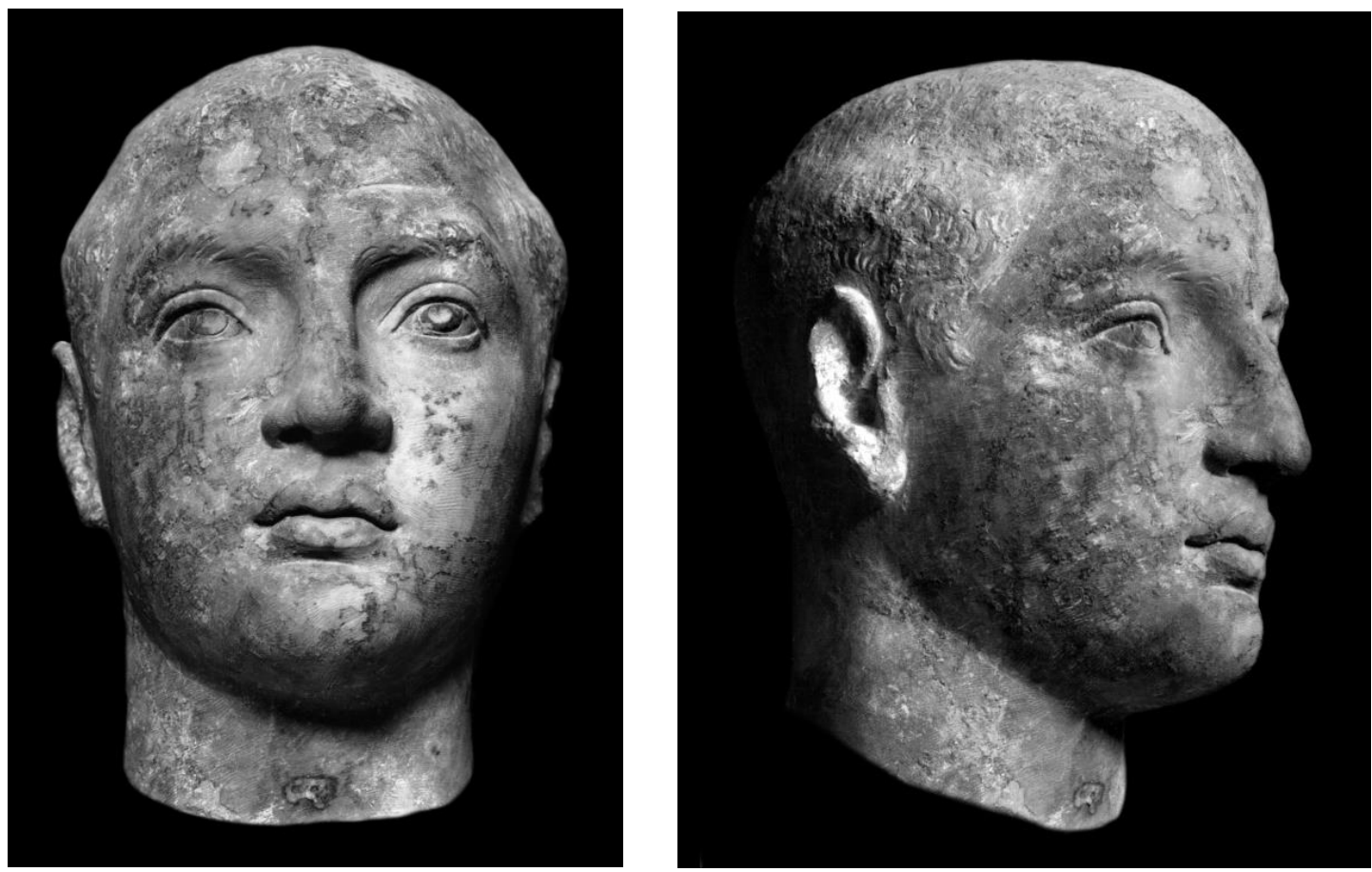

FIG. 17 a-b - Ephebe. Athens, National Archaeological Museum, inv. 79391 Photo: Negs. DAI Abt. Athen, NM $75 a$. 

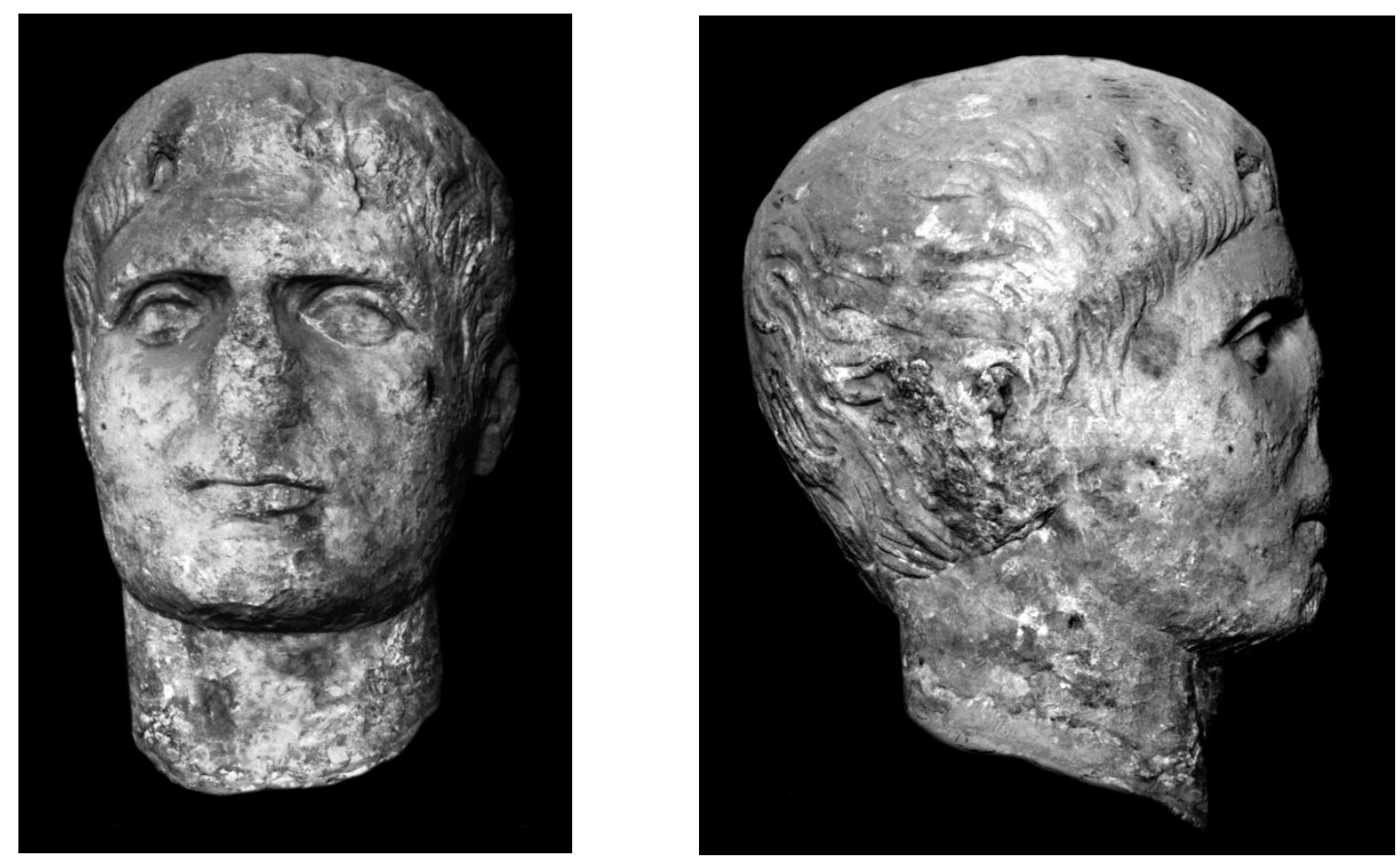

FIG. 18 - Ephebe. Athens, National Archaeological Museum, inv. 401. Photo: Negs. DAI Abt. Athen, NM 89a.

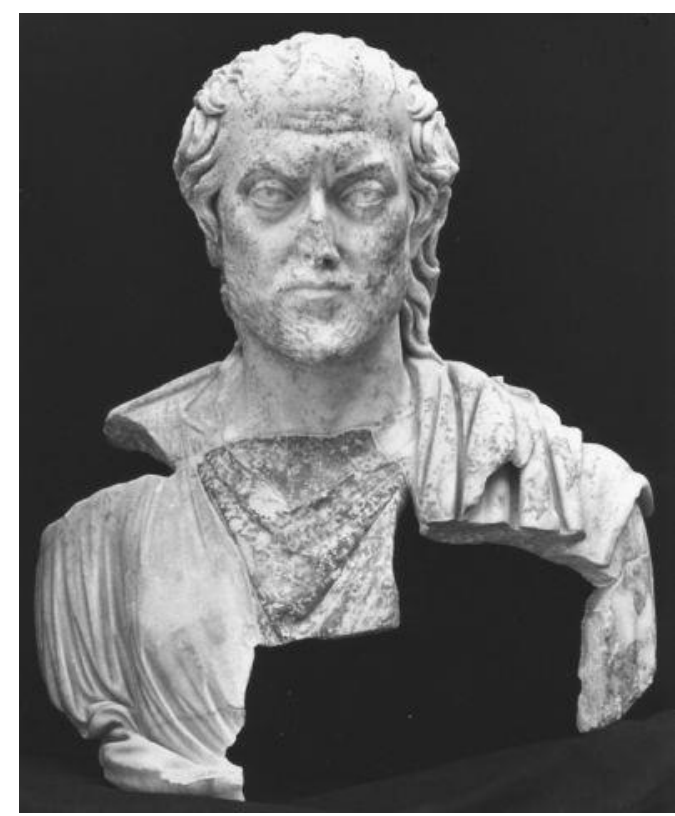

FIG. 19 - 'Sophist'. Aphrodisias, Aphrodisias Museum, exc. inv. 81-107 and 111. Photo: LSA-203.

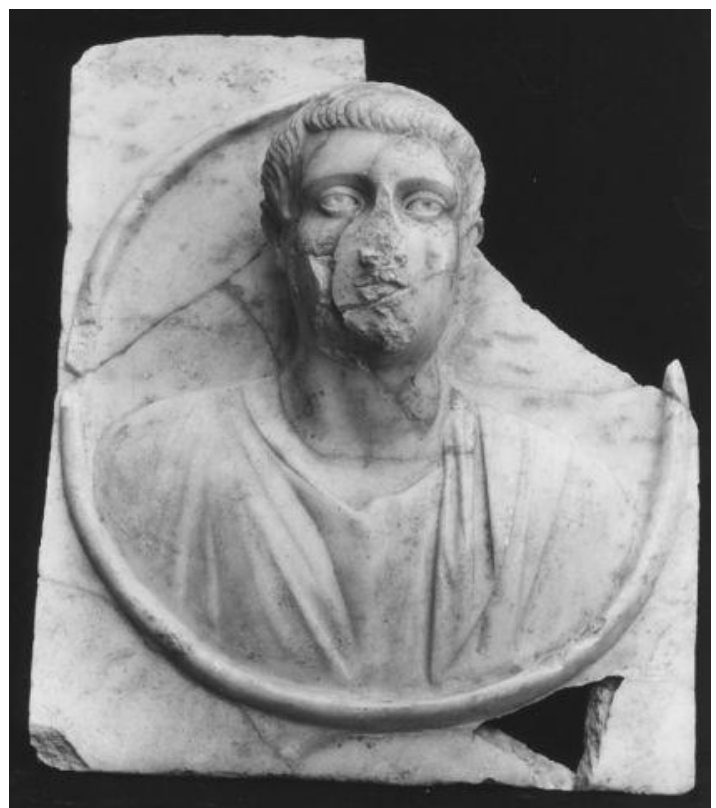

FIG. 20 - Youth, imago clipeata. Aphrodisias Museum, exc. inv. 81-137. Photo: LSA-209. 
FIG. 21 - Herodes Atticus. Paris, Louvre, inv. Ma1164. Photo: Wikimedia Commons. Photo: Marie-Lan Nguyen for Wikimedia Commons, license CC BY 3.0.

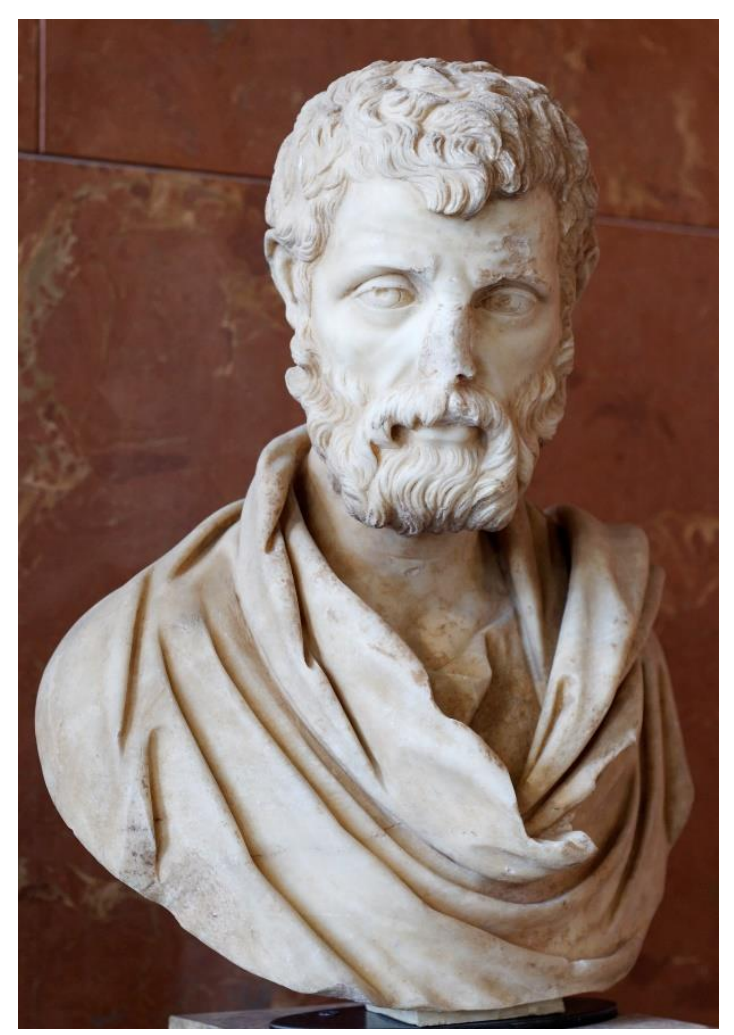


